\title{
EL PODER DEL JUEZ ADMINISTRATIVO DE LIMITAR LAS COSTAS PROCESALES
}

\author{
CÉSAR CIERCO SEIRA ${ }^{\top}$ \\ Universidad de Lleida \\ cesar@dpub.udl.es
}

Cómo citar/Citation

Cierco Seira, C. (2017).

El poder del juez administrativo de limitar las costas procesales.

Revista de Administración Pública, 202, 43-89.

doi: https://doi.org/10.18042/cepc/rap.202.02

\section{Resumen}

El juez administrativo aparece investido con una facultad singular que va a permitirle moderar ex officio, según su prudente arbitrio, el contenido y alcance de la condena en costas procesales a la luz de las circunstancias particulares de cada caso. El uso de este poder ha desbordado los márgenes tradicionales de la casación, ámbito en el que se venía desenvolviendo con naturalidad, bien que con algún sobresalto, dando lugar a una serie de derivaciones, como las condenas simbólicas, que deben hacernos meditar sin falta acerca de las virtudes y limitaciones de esta generosa facultad. Y no solo eso. Las sendas que transita hoy este poder de limitación de las costas nos ponen sobre aviso de la posible existencia de disfunciones más profundas, de desajustes en nuestro sistema de costas procesales que están en grado de comprometer el acceso a la justicia administrativa.

\section{Palabras clave}

Costas procesales; justicia administrativa; derecho de acceso a los tribunales.

1 Profesor titular de Derecho Administrativo. 


\begin{abstract}
Administrative law judges have a singular power that enables them to moderate, ex officio, at their careful discretion, and based on each case's specific circumstances, the content and extent of legal costs awarded. The use of this generous power has gone beyond the traditional boundaries of annulment, within which it has been employed without complications, albeit with occasional surprises, leading to a series of consequences, such as symbolic rulings, which make pondering its virtues and limitations a necessity. Additionally, the current uses of this power constitute a warning as to the possible existence of greater dysfunctions, of flaws in our system of legal costs which could put access to administrative justice in jeopardy.
\end{abstract}

\title{
Keywords
}

Legal expenses; administrative justice; the right to access to court. 


\section{SUMARIO}

I. INTRODUCCIÓN: DE LA IMPORTANCIA DE LA CERTEZA EN EL FUNCIONAMIENTO GENERAL DE LAS COSTAS PROCESALES Y, SINGULARMENTE, EN LO QUE HACE A SU PROYECCIÓN SOBRE LA JUSTICIA ADMINISTRATIVA. II. UN PODER DEL JUEZ ADMINISTRATIVO ORIGINAL, PENETRANTE Y EXTRAORDINARIO. III. LA RAZÓN DE SER ÚLTIMA DE LA CLÁUSULA DE LIMITACIÓN DE LAS COSTAS PROCESALES EN LA JUSTICIA ADMINISTRATIVA Y LA INSTRUMENTACIÓN QUE DE LA MISMA VIENE HACIÉNDOSE POR EL JUEZ ADMINISTRATIVO A CUENTA DE LA CORRECCIÓN DE CIERTAS DESVIACIONES DEL SISTEMA: 1. El prudente arbitrio judicial al servicio de la limitación casuística de los efectos de las costas procesales. 2. La dificultad de sistematizar y ofrecer un cuadro claro de los supuestos en los que es dado activar esta facultad moduladora. La motivación relajada como regla. 3. Las justificaciones más corrientes que ofrece el juez administrativo: el trabajo de la parte vencedora, la entidad de la causa y la concurrencia de vencedores. IV. LAS MODALIDADES Y EL ALCANCE DE LA MODERACIÓN DE LAS COSTAS PROCESALES: 1. Las modalidades en que puede concretarse la moderación: la condena parcial y/o hasta una cifra máxima. 2. El enigma de la cifra máxima. Las luces de los criterios internos y las sombras de la incoherencia del conjunto. 3. El fenómeno de las condenas simbólicas - la advertencia de un serio problema de adaptación del criterio del vencimiento objetivo a ciertos contenciosos. 4. La limitación selectiva de las partidas y el grave agravio comparativo surgido entre abogados y procuradores a raíz de este modus operandi. V. POR UNA REFORMA LEGAL SUSTANCIAL DE NUESTRO SISTEMA DE COSTAS PROCESALES Y UNA RECONSIDERACIÓN EN CLAVE JUDICIAL DE LA FORMA DE MOTIVAR LA UTILIZACIÓN DE SUS ACTUALES RESORTES.

\section{INTRODUCCIÓN: DE LA IMPORTANCIA DE LA CERTEZA EN EL FUNCIONAMIENTO GENERAL DE LAS COSTAS PROCESALES Y, SINGULARMENTE, EN LO QUE HACE A SU PROYECCIÓN SOBRE LA JUSTICIA ADMINISTRATIVA}

La reflexión sobre las costas procesales es asunto en el que conviene aplicarse a fondo. Aunque aparentemente puedan tenerse por un apéndice menor, por tema que solo forma parte de los créditos de la contienda judicial, lo 
cierto es que las costas procesales vienen a desempeñar un papel importante en el funcionamiento de la justicia. Y conste que no es solo por la relevancia práctica que adquieren a la hora de acentuar el significado de la derrota, más dolorosa, claro está, si viene acompañada de la condena a cargar con las litis expensas del contrincante ${ }^{2}$. Importa también tener presente en todo momento que las costas procesales albergan la aptitud y la potencia suficiente en orden a influir y aun condicionar la decisión de acceder a la justicia.

Valga lo anteriormente afirmado para cualquier rama de la justicia. Si, además, hablamos de la justicia administrativa, la cosa se torna todavía más seria. Las rémoras y los obstáculos que dificultan llevar a juicio a la Administración han de someterse a un rasero riguroso. Hace falta, en efecto, extremar el celo y mostrarse riguroso cuando se trata de justificar el establecimiento de límites económicos capaces de disuadir al particular de llevar la causa que tiene con la Administración ante los tribunales. Y ello por dos razones de peso que no siempre se resaltan en la medida esperable. La primera: que la fiscalización judicial de la actividad administrativa es corolario del sometimiento de la Administración al imperio de la Ley y que, en consecuencia, allí donde se dirime el recto hacer de su actuación se produce una reafirmación del principio de legalidad que a todos nos concierne y que otorga a estas demandas una trascendencia social acentuada. La segunda: que hay en estas contiendas un desequilibrio de partida entre las posiciones que ocupan el particular y la Administración, que de ordinario llega a la arena judicial con ventaja. Súmense ambos postulados y se obtendrá la firme necesidad de interpretar el derecho de acceso a la justicia administrativa con generosidad y, por consiguiente, con poco margen para que se utilice el «bolsillo» como posible factor de disuasión.

El alegato acerca de la importancia de parar mientes y desconfiar de las trabas y obstáculos en el acceso a la justicia administrativa no supone la censura radical de toda limitación de orden económico. A mi juicio, no es proposición defendible, al menos no con carácter apodíctico, la presencia de costas procesales, ya como vía de redistribución de gastos del proceso, ya como sanción de conductas temerarias y/o maliciosas, en sede contencioso-administrativa.

2 Aunque soy consciente de que el término "condena» en el ámbito de las costas procesales ha perdido precisión a medida que se ha ido instalando como canon general la victoria procesal - la idea de condena es propia de entornos donde manda el criterio de la temeridad y/o mala fe y en los que, por tanto, la imposición de costas incorpora un componente de reproche a la conducta; en cambio, allí donde rige el criterio del vencimiento la imposición de costas es aséptica en el sentido de que solo busca resarcir al litigante vencedor al que le asistía la razón para acudir a juicio o defenderse en él一, he decidido en este trabajo seguir usándolo por entender que su expresividad ayuda a seguir mejor el hilo discursivo. 
El dilema no es si la justicia administrativa admite desde un punto de vista ontológico la instauración de un sistema de costas procesales a la manera de otros órdenes jurisdiccionales. El quid estriba en interiorizar que, de hacerlo, hay que operar con mucho tino y no sirven las meras extrapolaciones. En otro lugar he tratado de significar que la opción entre uno de los dos criterios universales — vencimiento versus temeridad - tiene aquí implicaciones de fuste y que, en lugar de calcar esquemas del derecho procesal común, convendría ajustar la regulación de las costas procesales en la justicia administrativa hasta que estuviese el grado de dar respuesta a su idiosincrasia ${ }^{3}$.

La almendra de un sistema de costas procesales cabal pasa, desde luego, por la elección y modelación de las reglas de reparto. Pero no solo eso. Es necesario, además, que el sistema, en su conjunto, cualquiera que sea la opción finalmente escogida, resulte previsible. La previsibilidad constituye, en efecto, una propiedad fundamental, esencial, de las costas procesales. Lógicamente, no se reclama una certidumbre absoluta, de suyo inalcanzable si tenemos en cuenta que va a influir en la suerte de las costas procesales un acontecimiento futuro de pronóstico incierto cual es el desenlace de la contienda. Pero, esto supuesto, la regulación jurídica de las costas procesales ha de ser lo más clara posible en cuanto a su funcionamiento a fin de que sea dado al justiciable inteligir cuáles son las reglas de juego y formarse una idea consciente de las consecuencias en caso de victoria o de derrota ${ }^{4}$.

Costas procesales suficientemente precisas y comprensibles para no entorpecer el acceso a una rama de la justicia especialmente sensible. Teniendo esto presente, he ahí la pregunta que cabe poner hoy sobre el tapete: ¿̨hay suficiente certeza en las reglas que marcan la atribución de las costas procesales en la justicia administrativa? ¿Ofrece nuestra ley pautas seguras al justiciable que ha de enfrentarse al poder público acerca de cómo se resolverá el onus expen-

3 Me sea permitido remitir al lector a mi trabajo C. Cierco Seira (2016), «Las costas procesales y el derecho de acceso a la justicia administrativa», en J. Agudo González (dir.), Control administrativo y justicia administrativa, Madrid: INAP, págs. 103-149.

4 Huelga a mi juicio abundar en la importancia de la previsibilidad en un sistema de costas procesales. En todo caso, quisiera rescatar aquí un texto a menudo olvidado para remarcar esta idea en el plano práctico: la Carta de derechos de los ciudadanos ante la Justicia - aprobada por el Pleno del Congreso de los Diputados, por unanimidad, como proposición no de ley el 16 de abril de 2002 - En este texto, destinado a ser algo más que una declaración de principios, se aborda el tema de las costas procesales $y$, entre otras cosas, se dice que: "El ciudadano tiene derecho a ser informado por su Abogado y por su Procurador, con carácter previo al ejercicio de cualquier pretensión ante un órgano judicial, sobre las consecuencias de ser condenado al pago de las costas del proceso y sobre su cuantía estimada» (\$ 39). 
sarum? Y, si la calidad de la ley desfallece, ¿colma esta ausencia de previsión la jurisprudencia aplicativa?

Pues bien, me temo que no. No, al menos, con el grado de previsión que sería de esperar. Y en ello influye un curioso factor que será justamente el centro de este trabajo. Se trata del poder concedido al juez administrativo para limitar la imposición de las costas. Así reza el art. 139. 4 de la LJCA: «La imposición de las costas podrá ser a la totalidad, a una parte de éstas o hasta una cifra máxima ${ }^{5}$ ».

Pocas palabras, ciertamente, para dar forma a una potestad formidable. Capaz, como se verá, de poner por sí sola en jaque la virtualidad de todo el entramado de costas procesales. $Y$ es que, aunque en apariencia pueda pensarse que se está ante una cláusula residual, llamada a operar ocasionalmente, la realidad se ha encargado de demostrar que su concurso en la justicia administrativa, lejos de ser algo raro y prescindible, pasa por ser moneda corriente cuyo valor, con el paso del tiempo, no ha cejado de ir en aumento hasta convertirse, hoy por hoy, en una pieza destacada en el funcionamiento cotidiano del engranaje de las costas procesales en lo contencioso-administrativo. A lo ancho de la planta judicial de lo contencioso-administrativo hallamos testimonios recurrentes de su manejo. Y otro tanto ocurre si miramos por instancias. No es solo poder que se active en la primera instancia. También se hace uso frecuente del mismo en apelación y aun en casación. De hecho, es el Tribunal Supremo, a través de la casación, precisamente, uno de sus grandes valedores, como habrá ocasión de ver.

El objetivo de este trabajo es estudiar con detalle la virtualidad de esta potestad a la luz de la aplicación que de la misma viene haciéndose por nuestros tribunales. Y ello con la preocupación por la incertidumbre que se ha instalado en su derredor. Aunque, a la constatación y explicación de todo ello, se une, lo adelanto ya, una idea-fuerza que va a recorrer este trabajo: el uso del poder de limitar las costas procesales deja vislumbrar en el trasfondo la búsqueda resuelta por parte del juez administrativo de salientes a los que aferrarse para ofrecer respuestas armónicas sobre el coste del proceso contencioso-administrativo, enderezando situaciones que no aciertan a resolver las reglas ordinarias en la materia. Una luz de alerta, si se quiere. Una señal que nos indica que urge volver sin falta sobre la base de nuestro modelo de costas procesales.

5 Conviene puntualizar que la numeración actual es reciente y trae causa de la reforma llevada a cabo por la Ley Orgánica 7/2015, de 21 de julio. Hasta entonces, el poder de limitar las costas procesales venía ocupando el apartado tercero, que es el que aparece en la mayor parte de los pronunciamientos judiciales que serán citados. 
De manera que nos encontramos, en suma, ante una cláusula que, no obstante su modesta carta de presentación, se revela hoy en la práctica vivaz, tanto por su vitalidad como por el ingenio que encierra en su interior.

\section{UN PODER DEL JUEZ ADMINISTRATIVO ORIGINAL, PENETRANTE Y EXTRAORDINARIO}

En la primera toma de contacto con el poder de limitar la imposición de costas es conveniente hacer parada en una serie de rasgos que de inmediato nos ponen sobre la pista de lo llamativo de esta perla.

A. El examen no puede arrancar sino destacando, de entrada, la originalidad de esta cláusula. Tan es así que dentro del arco judicial solamente al juez administrativo se le ha investido con una facultad de este signo. Fuera de los dominios de lo contencioso-administrativo no hay rastro de una previsión que posibilite la limitación del contenido de la condena en costas a criterio del órgano jurisdiccional.

Acaso la lectura del art. 139.4 de la LJCA evoque algunas restricciones en el alcance de las costas procesales, como el tope de la tercera parte de la cuantía del proceso que recoge el art. 394.3 de la Ley de Enjuiciamiento Civil respecto de abogados y demás profesionales sin honorarios reglados ${ }^{6}$; o, también, los techos establecidos por la Ley reguladora de la jurisdicción social a propósito

$6 \quad$ El art. 394.3 de la LEC tiene su precedente inmediato en el art. 523.3 de la vieja LEC. Dicha previsión fue introducida, para ser más precisos, por obra de la Ley 34/1984, de 6 de agosto, de reforma urgente de la Ley de Enjuiciamiento Civil.

Por cierto que la convivencia del límite legal del art. 394.3 de la LEC con la facultad moderadora del art. 139.4 de la LJCA no está exenta de problemas. Y es que, como es sabido, la LEC ocupa, en lo que respecta a la justicia administrativa, una singular posición basada en la supletoriedad general que recoge la disposición final primera de la LJCA y que se reafirma en no pocas remisiones concretas, incluida una en relación precisamente con las costas procesales (art. 139.7). Siendo esto así, se ha planteado en qué medida la limitación acordada al amparo del art. 139.4 de la LJCA puede hacer excepción del límite de un tercio o, lo que es lo mismo, si ha de considerarse al art. 394.3 de la LEC como un punto de partida que solo admite mejora y en ningún caso empeoramiento. Pues bien, lo cierto es que el TS se ha cuidado de poner a resguardo la singularidad del poder moderador del juez administrativo, seńalando que hay que estar a la limitación establecida a su amparo, sin que resulte procedente discutir en tasación el importe así obtenido por más que se aparte de lo establecido en el art. 394.3 de la LEC. Véanse, ex multis: AATS de 30 de octubre de 2014 (recurso 3466/2011) y de 17 de septiembre de 2015 (recurso 146/2009). 
de las minutas de los abogados y graduados sociales ${ }^{7}$. Estas previsiones constituyen todas ellas exponentes de la voluntad de preservar los márgenes razonables de las costas procesales a fin de que estas no acaben convirtiéndose en un fardo desmesurado sobre la espalda del perdedor; inquietud con la mirada puesta, señaladamente, en la minuta del abogado; no vaya a ser que los honorarios del letrado, luego de haber vencido, se giren sin contemplaciones y estirando al máximo la cuerda. Para frenar este impulso y lograr la contención en la factura de las costas procesales se opta por el establecimiento de un límite legal.

Es seguro que un tal sentir está presente también en la ratio legis del art. 139.4 de la LJCA. Desde esta óptica es reconocible, en efecto, una cierta comunión y al cabo la existencia de una línea de pensamiento común en la codificación procesal española en lo que hace a la preocupación por la moderación de las costas procesales. Se conoce que las costas procesales han de ser moderadas a fin de que el proceso judicial, expresión de la impartición de justicia, sirva al noble fin que le corresponde. Y aunque sea esta una propiedad consustancial a la institución - no en balde luce como principio básico en las normas orientadores de los Colegios de abogados-, se teme al cabo que la complejidad y vastedad que caracteriza al tablero judicial pueda devenir en una tela de arańa capaz de alterar su signo provocando a la postre el empobrecimiento del perdedor más de lo que el equilibrio económico del pleito admite. Es por todo ello que se establecen ciertas líneas rojas que, consignadas en la ley, enmarcan con rigidez el ejercicio de moderación indispensable a que han de ser sometidas por sistema las costas procesales.

Ahora bien, esto sentado, el salto que con respecto a la LEC y a la LRJS ofrece la LJCA es harto sustancial. Adviértase así que el art. 139.4 de la LJCA no pone el foco exclusivamente, ni principalmente, en la minuta del abogado, sino que deja vía franca para actuar sobre cualquiera de las partidas que integran las costas del proceso. Y lo que es más relevante: la interpositio legislatoris no se traduce aquí en el establecimiento directo de un límite legal a acatar sino que se traslada la limitación a otro momento, dejando que sea el juez

\footnotetext{
Encontramos en dicha ley la presencia de límites a los honorarios de abogados y graduados sociales. Así, en las costas resultantes de la no asistencia al acto de conciliación o de mediación, donde opera el límite de seiscientos euros (art. 66.3); el mismo que se prevé en caso de temeridad o mala fe por parte del empresario (art. 97.3). También en las costas relativas al recurso de suplicación se establece que dichos honorarios no podrán superar la cantidad de mil doscientos euros (art. 235.1); o, en fin, en las que atañen al recurso de casación cuyo tope - siempre en concepto de las citadas remuneraciones profesionales - serán los mil ochocientos euros (art. 235.1).
} 
administrativo quien module casuísticamente y según su prudente arbitrio el contenido de la condena en costas allí donde lo considere oportuno.

B. Si original resulta el establecimiento de esta potestad no menos singular es su virtualidad. Y es que basta reparar un instante en la redacción del art. 139.4 de la LJCA para caer en la cuenta de que el poder conferido no es exactamente el de neutralizar por causa justificada la imposición de las costas sino algo distinto: el de limitar o recortar su contenido. La ley autoriza, en otras palabras, a que el juez administrativo lleve a cabo una novación objetiva del crédito originado de resultas de la condena en costas, lo cual supone, ni más ni menos, adentrarse en una órbita distinta a su giro habitual, cercana, se diría, a la labor de tasación. De manera que, al resolver la contienda o alguna de sus derivaciones, habrá de ocuparse aquel de la imposición de las costas procesales, con el margen de maniobra correspondiente, pero podrá, sobre ello, interferir en su tasación. Planteamiento este que, como ya se habrá intuido, está en el origen de ciertos problemas prácticos de confusión de planos y roles 8 .

8 La limitación de las costas procesales no ha de confundirse en ningún caso con su tasación. Esta última persigue el escrutinio de las partidas de las costas procesales y la verificación de la rectitud de su importe. La limitación, en cambio, pasa por ser una operación previa cuya finalidad es establecer una moderación, por medio de alguna de las modalidades a las que se hará mención, del resultado final de la condena en costas. Sobre el papel, por tanto, son dos funciones perfectamente conjugables. Es más, se diría que su concurso ofrece importantes ventajas. La limitación al fin y al cabo va a allanar el camino de la tasación posterior, enmarcándola y reduciendo, señaladamente, el problema de las costas excesivas, pero también imprimiendo una capa de seguridad — quién sabe si incluso facilitando, de resultas de la limitación, su exacción y cobro, que es extremo particularmente espinoso- En este sentido, es de señalar que el TS tiene establecido que, salvo casos excepcionales, la tasación practicada dentro de los márgenes fijados en la limitación no puede reputarse excesiva (véase, últimamente, por ejemplo, el ATS de 2 de junio de 2016, recurso 537/2015).

La realidad, de todos modos, se cuida de recordarnos que las cosas no son tan sencillas siempre. De resultas del casuismo tan acentuado que caracteriza a esta facultad no faltan los problemas técnicos de ajuste. Hay así supuestos en los que la limitación resulta tan precisa que apenas deja espacio. También los hay en los que el tope establecido es tan alto que, en lugar de reducir el problema de las costas excesivas, lo enturbia. Sin olvidar, en fin, las complicaciones adicionales a que da lugar la opción de moderar únicamente tal o cual partida. Es entonces cuando más se difumina, como veremos más adelante, la línea divisoria que separa ambas funciones.

Esto supuesto, y aun reconociendo las posibles ventajas de la limitación de cara a la tasación, es importante dejar claro que la limitación no supone vaciar de contenido a la tasación ni constituye una suerte de prevención frente a su ineficacia. Y no solo eso. 
C. En íntima conexión con lo que acaba de decirse está su carácter excepcional en el esquema inicial de las costas procesales. La letra de la ley no transmite, es cierto, este rasgo. Ello no obstante, parece llano que el poder para limitar las costas procesales presupone la existencia de una condena en tal sentido y que, por consiguiente, actúa en defecto de otros mecanismos de compensación o ajuste llamados a actuar sobre el hecho de la condena. La reducción solo tiene sentido si se ha descartado previamente la opción de dejar el reparto in tabulas, por considerar, por ejemplo, que el caso presentaba serias dudas de hecho o de derecho?.

D. Finalmente, para cerrar esta primera aproximación no puede por menos que ser significado lo que representa esta facultad en términos de posición institucional del juez administrativo. Se fía a su prudente arbitrio la atenuación de la condena en costas en el entendido de que es el mejor situado, por su proximidad y conocimiento de causa, para apreciar la justeza del peso económico que el onus expensarum representa para el perdedor al trasluz del pleito. Asistimos, así pues, a una muestra de la particular misión confiada al juez administrativo y que se traduce aquí en el otorgamiento de un poder original ${ }^{10}$. Poder que se suma a otros de dirección en la llevanza de los pleitos de esta rama como el de poner sobre el tapete argumentos, motivos no introducidos por las partes ${ }^{11}$.

Constituye un error poner el acento en esta faceta, subrayando la facilitación tasadora en su tarjeta de presentación. No es esta su razón de ser.

9 Excluidas las vías de neutralización del vencimiento es entonces el momento de recurrir a la posibilidad que brinda el art. 139.4 de la LJCA si así se juzga oportuno para equilibrar el impacto de la condena en costas y mitigar sus efectos sobre la parte vencida.

10 Atribución que no es baladí. Tengo en mucho la potestad de limitar las costas procesales pues entiendo que su influencia en la modelación del acceso a la justicia administrativa puede ser significativa. De ahí que sea una señal clara de la confianza depositada en el juez administrativo.

11 Ex art. 33.2 de la LJCA. Lo que permite, por cierto, insistir en cómo la aguda singularidad de la justicia administrativa debiera dejarse notar en el régimen de costas procesales: «cuando la Ley asocia de manera directamente causal el rechazo de las pretensiones a la condena en costas, obviamente está pensando, o al menos partiendo de la base conceptual, de pretensiones ejercitadas - y previamente decididas, conforme al principio dispositivo, por la libre voluntad de esa parte procesal—, probablemente no advierte, quizá porque la norma se ha importado de forma automática del proceso civil, que en el contencioso-administrativo el litigio se puede fallar por razón de la concurrencia de motivos de nulidad diferentes a aquellos suscitados por las partes en sus escritos rectores, planteados por el órgano judicial en uso de sus atribuciones procesales» - J. Navarro Sanchís (2011), «El nuevo régimen de la condena en costas 
Es facultad, pues, cuya activación queda a disposición del juez administrativo. Cuestión distinta es que las partes puedan interesar el uso de la misma. Por cierto que ya no es raro en este sentido que el art. 139.4 de la LJCA haga asomo en el suplico de demandas y contestaciones a modo de petición subsidiaria para el caso de que tenga lugar una condena en $\operatorname{costas}^{12}$. ¡Incluso las hay que, rizando el rizo, sugieren al juez o tribunal la cifra máxima a establecer ${ }^{13}$ !

\section{LA RAZÓN DE SER ÚLTIMA DE LA CLÁUSULA DE LIMITACIÓN DE LAS COSTAS PROCESALES EN LA JUSTICIA ADMINISTRATIVA Y LA INSTRUMENTACIÓN QUE DE LA MISMA VIENE HACIÉNDOSE POR EL JUEZ ADMINISTRATIVO A CUENTA DE LA CORRECCIÓN DE CIERTAS DESVIACIONES DEL SISTEMA}

\section{EL PRUDENTE ARBITRIO JUDICIAL AL SERVICIO DE LA LIMITACIÓN CASUÍSTICA DE LOS EFECTOS DE LAS COSTAS PROCESALES}

El poder para modular las costas procesales que recoge el art. 139.4 de la LJCA se confiere al juez administrativo con el propósito de que corrija a mano las eventuales desviaciones en que pueda incurrir el sistema in concreto. Es así una facultad que busca preservar la moderación de las costas procesales atendidas las circunstancias del caso en cuestión ${ }^{14}$.

en la Ley de la Jurisdicción Contencioso-Administrativa», Actualidad Administrativa, 21-22, págs. 2653-2668 (pág. 2658).

12 Es lógica la inclinación de las partes al inicio del proceso de tratar de minimizar los daños para el caso de derrota y a este respecto la invocación del art. 139.4 de la LJCA se antoja una prevención más por si acaso: si pierdo, modérese el alcance de las costas por vencimiento. De ahí que, por más que sea un poder en manos del juez administrativo y con un componente de arbitrio judicial altísimo, sea de recibo que se perfile de la mejor manera posible a los efectos de permitir que sobre ella se forme un criterio, así sea con reservas, el justiciable. En suma, que el otrosí destinado a pedir la activación del poder de limitación en el caso de una hipotética condena pueda incorporar una justificación hecha con referentes, con información adecuada, y no se convierta en un pedimento hecho a ciegas.

13 Véase el supuesto fallado por el Auto de aclaración de la AN de 1 de septiembre de 2014 (trámite de aclaración núm. 278/2013).

14 El arbitrio judicial otorgado en este supuesto pretende corregir la generalidad natural de la ley y, a la par, confiar en la serenidad y oficio del órgano sentenciador para moderar el resultado de las costas. En palabras de A. Nieto que hacen aquí al caso: «la equidad sólo 
Su origen apunta en esta dirección. El poder de limitar las costas adquirió carta de naturaleza con la LJCA de 1998, fruto de los debates y negociaciones habidos en su gestación parlamentaria. Cumple recordar que en el proyecto de ley se apostaba por dar un giro en materia de costas procesales a fin de acoger como canon general a la regla victus victori. Sin embargo, a su paso por las Cortes Generales, un tal planteamiento fue objeto de un interesante debate; hubo disquisiciones sobre la singularidad de la justicia administrativa y se señalaron las disfunciones que podía traer consigo la recepción de un modelo generalizado de vencimiento. Al cabo, la réplica a la opción inicial prosperó y se replanteó la regulación: iba a mantenerse el criterio tradicional de la temeritas y/o mala fides para la primera instancia contencioso-administrativa. Por cierto que no me resisto a señalar que el argumento fundamental que bloqueó la llegada del vencimiento y mantuvo a la temeridad en la base del sistema no tuvo que ver con la reafirmación de la superioridad ontológica del criterio subjetivo sino con el temor a la disuasión que provocaría la incorporación del criterio de la soccombenza. Aun con sus notorias carencias, conocidas y bien denunciadas, se consideró que la temeridad ensanchaba al cabo el camino a la justicia administrativa. Curiosamente, esa perspectiva iba a cambiar radicalmente años después. Lo que en 1998 se estimaba un precio demasiado alto, en 2011, con la litigiosidad en ascenso decidido, se convirtió en la piedra de toque para el desembarco final de la regla victus victori en el primer estadio de lo contencioso-administrativo.

Retomando el hilo discursivo, ocurrió que, precisamente con ocasión de estos debates sobre el rumbo a seguir en tema de costas procesales, se "coló» la idea de tratar de redondear el sistema con una previsión destinada a prevenir posibles excesos. Así, de forma más bien discreta, se articuló el poder del juez administrativo de mitigar las costas impuestas para impedir que la economía final del pleito se viese descompensada de resultas de la factura de los profesionales intervinientes en él.

Elucidar la motivación última de este poder modulador no resulta complicado, en efecto, si nos elevamos al plano abstracto y traemos a colación ese ideal de ajustar con precisión el fiel de la balanza de las costas procesales. Ahora bien, hace falta para desentrañar la inteligencia de este poder de limitación descender a un plano, al menos, intermedio ${ }^{15}$.

puede hacerse efectiva a través del arbitrio, dado que únicamente el juez —y no la leyconoce las circunstancias singulares del caso concreto y está en condiciones, por tanto, de adaptar la ley a ellas. O la ley se fía del juez o no hay explicación posible de las decisiones de equidad» - A. Nieto (2007), El arbitrio judicial, Barcelona: Ariel (pág. 234).

15 Con todo, el alto grado de discreción reconocido al juez administrativo no pasó desapercibido a la doctrina científica que sin falta se cuidó de significar el riesgo de inse- 
Se trata, así pues, de un artilugio ideado para velar por el equilibrio y la armonía de un sistema de costas procesales que ha de aplicarse en un ámbito muy singular. Y es esta una imagen que se ve reforzada por su propia ubicación sistemática: dispuesta como una atalaya que queda en solitario, en un apartado específico, desde el que puede vigilar con plenitud y proyectarse sobre cualquier grado o instancia de lo contencioso-administrativo ${ }^{16}$.

Esta misión general de corrección casuística y artesana de todo el edificio de las costas procesales hace que la proyección de esta previsión admita un recorrido rico en matices y posibilidades. Adviértase, por de pronto, que la cláusula de marras no está de hecho cosida a un modelo concreto de costas procesales. Hoy, sí, se utiliza básicamente para tratar de mitigar los rigores de un sistema presidido por el vencimiento. Aun así, es perfectamente dable que pueda ser empleada allí donde mande otro criterio. Elocuente es el hecho de que el tenor literal del art. 139.4 de la LJCA no haya sufrido mutación alguna en el tránsito hecho desde la temeridad y/o mala fe, que era el eje de la condena en costas en la primera instancia de la justicia administrativa en 1998, al vencimiento, adoptado en 2011 como canon general en todas las instancias. A pesar de la profundidad del cambio, la formulación del poder de limitación ha seguido intacta. Y lo mismo puede decirse de la reciente reforma de las costas procesales en la casación ${ }^{17}$.

guridad jurídica a que se prestaba - A. Martínez Marín (1998), «Costas procesales», REDA, 100: "Comentarios a la Ley de la Jurisdicción Contencioso-Administrativa de 1998», págs. 907-917 (pág. 913).

16 De la versatilidad de esta facultad es demostrativo también el hecho de que la misma se emplee no solo a propósito de la condena en costas al término de la contienda, sino también respecto de las actuaciones intermedias que puedan ir surgiendo a lo largo del iter procesal. Un detallado examen sobre el devengo de costas producto de los actos intermedios puede encontrarse en M. Ponte Fernández (2015), «Las costas procesales en el orden jurisdiccional contencioso-administrativo tras la Ley 37/2011, de 10 de octubre, de medidas de agilización procesal», Cuadernos Digitales de Formación, 6, CGPJ, págs. 6-12.

17 Hay que estar hoy a lo previsto en el nuevo art. 93.4 de la LJCA, cuya redacción procede de la Ley Orgánica 7/2015, de 21 de julio (disposición final tercera): «La sentencia que se dicte en el momento procesal a que se refiere el apartado 8 del artículo anterior, resolverá sobre las costas de la instancia conforme a lo establecido en el artículo 139.1 de esta ley y dispondrá, en cuanto a las del recurso de casación, que cada parte abone las causadas a su instancia y las comunes por mitad. No obstante, podrá imponer las del recurso de casación a una sola de ellas cuando la sentencia aprecie, y así lo motive, que ha actuado con mala fe o temeridad; imposición que podrá limitar a una parte de ellas o hasta una cifra máxima». 
Inmune, en definitiva, al criterium que rija en materia de costas procesales $^{18}$. Y, en esta misma línea, capaz de proteger, cualquiera que sea su condición, a la parte vencida. Importa significar a este respecto que no se está ante una cláusula estatuida únicamente ex parte civis, pensando, esto es, en la protección del particular, por más que sea este, de ordinario, la parte más débil en la arena contencioso-administrativa. Nada impide que el art. 139.4 de la LJCA sea aplicado también para limitar la condena en costas cuando esta viene a recaer sobre la Administración ${ }^{19}$. Aunque no sea

Amén de que se confirma, de forma expresa y acaso superflua — diría que es manifestación más bien de su profundo arraigo en el terreno casacional—, el poder de limitación de las costas procesales en la casación, interesa notar que se retorna al criterio de la temeridad y/o mala fe en este estadio. No es este el lugar para extenderme al respecto, pero quiero dejar apuntado que la novella es significativa para todo el sistema de costas procesales en lo que supone de recuperación de un criterio que muchas veces se da por amortizado y superado.

18 Lo cual no quiere decir que el comportamiento de esta facultad moderadora vaya a ser el mismo. En líneas generales, la moderación de la condena en costas encuentra un ambiente más proclive cuando se trata de mitigar los rigores de un modelo objetivo de vencimiento y su justificación resulta tanto más fácil cuanto mayor es el grado de rigidez de aquel. Allí, en cambio, donde la condena responde a cánones subjetivos resulta más difícil que la limitación se abra paso. No en vano, la posición tradicional frente a las conductas temerarias en el proceso judicial se orienta precisamente en una dirección diametralmente opuesta a la moderación. Vemos así que en el proceso civil el reproche al litigante temerario desactiva el límite legal de un tercio en las costas procesales (art. 394.3 de la LEC) y, de asomarnos al derecho comparado, es llamativa la introducción de instrumentos destinados a combatir el abuso procesal y el manejo frívolo de la justicia, incluida la rama administrativa - a retener, en este sentido, las interesantes previsiones en materia de spese di giudizio recogidas en el art. 26 del Codice del processo amministrativo italiano y glosadas, entre otros, por F. G. Scoca (2014), "Il "costo" del processo tra misura di efficienza e ostacolo all'acceso", Dir. Proc. Amm., 4/2014, págs. 1414-1433-. Por consiguiente, aunque un poder de moderación como el que nos ocupa tenga cabida en cualquiera de los dos grandes modelos de distribución de las costas procesales, no hay duda de que su maniobrabilidad se amplía en presencia del vencimiento.

19 Comprendo que esto último puede chocar. En efecto, desde la perspectiva del particular, el empleo de esta facultad moderadora para proteger a la Administración puede interpretarse como un cierto retorno a la tradicional ventaja que en materia de costas procesales ha disfrutado aquella desde antiguo. Los ecos del auténtico privilegio que la desafortunada aplicación del criterio de la temeridad había traído consigo todavía están muy presentes. No en vano, la llegada del vencimiento a la justicia administrativa ha tenido siempre entre sus principales motivaciones la voluntad de acabar de 
partidario de una simetría perfecta en materia de costas procesales, supuesta la desigualdad que media entre el particular y la Administración respecto del hecho del proceso, entiendo que cerrar a cal y canto las puertas del art. 139.4 de la LJCA a la Administración está fuera de lugar. Por lo común, salta a la vista que su aplicación tenderá a proteger al particular, rebajando el impacto de las consecuencias económicas de su derrota frente a la Administración. Pero, siendo esta la plantilla, no veo obstáculo que impida al juez administrativo que pueda servirse de esta cláusula a fin de que sea la

una vez por todas con la lenidad desesperante que el juez administrativo había venido demostrando al proyectar el canon de la temeritas sobre la Administración. Véanse, por todos, las críticas de G. Chiovenda (1901), La condanna nelle spese giudiziali, Torino: Fratelli Bocca Editori — manejo la reimpresión de Edizioni Scientifiche Italiane, Napoli, 2001-y, entre nosotros, de N. Alcalá-Zamora y Torres y N. Alcalá-Zamora y Castillo (1930), La condena en costas, Madrid: Imprenta del Colegio Nacional de Sordomudos.

Con este saber acumulado, no sería bueno que el art. 139.4 de la LJCA se convirtiese ahora en un refugio inesperado para la Administración. Conviene, por el contrario, que la instalación definitiva del vencimiento surta el efecto que tanta falta hace sobre la conciencia de la Administración. Porque hay que conseguir que cambie radicalmente su manera de contemplar las costas procesales y, por ende, el acceso a la justicia administrativa. No es en modo alguno admisible que «juegue» y se valga del precio del proceso como escollo capaz de frenar al particular pero intrascendente para ella; que siga en sus despachos el "vaya usted a juicio» como estratagema aliada de la terquedad huera. El de la justicia ha de ser camino recorrido con prudencia por todos, comenzando por la Administración.

Interiorizar que la justicia consume energías y esfuerzos importantes es un deber pendiente de nuestra Administración. Lo ha sido siempre porque, entre otras cosas, a veces se olvida que en el origen de su particular posición de imperio estuvo presente también la idea de reducir la litigiosidad mediante un buen uso de la vía administrativa previa. Pero se torna en nuestros días una exigencia todavía mayor a la luz de la gravedad de la crisis económica atravesada - acerca del impacto de esta crisis en el Derecho Administrativo sirva como texto de partida el estudio de J. M. Pemán Gavín (2016), «Crisis económica y cambios institucionales en Europa y en Espańa. Algunas reflexiones en torno a la crisis y las enseñanzas derivadas de la misma», en A. Ezquerra Huerva (dir.), Crisis económica y Derecho Administrativo, Cizur Menor: Aranzadi, págs. 27-94- Deja de ser explicable, si es que alguna vez lo fue, que la Administración no se tome en serio las posibles consecuencias económicas de sostener en pleito una posición sin motivos de peso o de demorar la solución de una controversia a la espera simplemente de que el particular baje los brazos. Por mor del principio de eficiente asignación de los escasos recursos públicos, hoy convertido en virtud señera de la Administración, tales actitudes deberían desaparecer del todo. 
Administración condenada la que vea limitada la imposición de las costas allí donde las circunstancias del pleito así lo justifiquen. Después de todo, la brecha entre el valor de lo controvertido y el impacto económico del

Aunque en líneas generales he de decir que no he advertido este riesgo en el uso del art. 139.4 de la LJCA, conviene estar en guardia. Me serviré para ilustrarlo del ejemplo que nos ofrece la SJCA núm. 1 de Ourense de 26 de enero de 2016 (recurso 270/2015). Se recurría en este asunto una sanción de tráfico por conducir sin cinturón de seguridad. La sanción era de 200 euros, con pérdida de tres puntos. La razón que asistía al particular era tan evidente como desaplicada había sido la conducta de la Administración en vía administrativa. No llevaba puesto el cinturón por razones médicas y, a pesar de haber aportado todos los certificados necesarios, la Administración se había limitado a seguir su marcha sin más. El relato del periplo del particular en la vía administrativa es demoledor y no me resisto a transcribirlo:

«Cuando el día 8 de marzo de 2015 los Agentes de tráfico detuvieron el vehículo en el que conducía el actor y le manifestaron que iban a denunciarle por no llevar el preceptivo cinturón de seguridad, éste les indicó que no podía, por razones médicas (malformación en el hombro izquierdo, con producción de dolor). Les exhibió un certificado médico oficial que llevaba en el vehículo, del año 2009, como ya había hecho otras veces que le habían parado por esa causa.

Como pese a ello se formuló la denuncia, el 18 de marzo de 2015 presentó escrito de alegaciones en la Jefatura Provincial de Tráfico de Ourense, explicando sus dolencias físicas y aportando tres certificados médicos oficiales de fechas respectivas 13 de mayo de 2010, 15 de febrero de 2013 y 11 de marzo de 2015, en el mismo sentido que el de 2009. En todos ellos se explicaban de manera detallada y clara las razones por las que el actor no podía llevar el cinturón de seguridad.

La Administración demandada no procedió a requerir de los agentes de tráfico una ratificación de la denuncia, ni un informe sobre las referidas alegaciones, dictando directamente la sanción de 200 euros con pérdida de tres puntos aquí impugnada. En la resolución sancionatoria no se le dedica ni una sola línea a lo alegado por el interesado. Posteriormente insistió en sus argumentos en su recurso de reposición. Y éste fue desestimado por la resolución de 14 de julio de 2015 también impugnada, con un texto de "modelo tipo", en el que tampoco se le dedica ni una sola línea a los argumentos del demandante».

La Administración, como estaba cantado, perdió el pleito y fue condenada en costas. Pero hete aquí que el juzgador decidió activar el art. 139.4 de la LJCA para establecer el límite de cien euros por los honorarios de abogado. Ignoro si con esa cantidad pudo cubrir el particular los gastos de su defensa pero, a mi modo de ver, estamos ante un supuesto en el que, en lugar de la moderación, se imponía, de haber existido, la agravación de las costas por manifiesta temeridad del contrincante.

Esto sentado, tampoco hay que caer sin más en una suerte de revanchismo que lleve a considerar que el criterio del vencimiento debe ser aplicado a todo trance a 
juicio también puede afectar gravemente, así sea de forma ocasional, a la Administración contendiente ${ }^{20}$.

\section{LA DIFICULTAD DE SISTEMATIZAR Y OFRECER UN CUADRO CLARO DE LOS SUPUESTOS EN LOS QUE ES DADO ACTIVAR ESTA FACULTAD MODULADORA. LA MOTIVACIÓN RELAJADA COMO REGLA}

La catalogación de los supuestos en los que viene haciéndose uso del art. 139.4 de la LJCA tropieza, de entrada, con la propia vocación casuística de la cláusula. Pero a esta complicación, de suyo inevitable, vienen a sumarse otros dos factores, estos sí de posible enderezamiento.

A. El primero tiene que ver con la propia formulación legal del precepto. Tal es la vaguedad del dictado que no solo no hay referencia alguna a los posibles móviles que han de perseguirse, sino que, sobre ello, ni siquiera se exige una explicación. Al menos, en otros pasajes de las costas, a pesar de la holgura, hay un llamamiento explícito a la motivación («salvo que aprecie $y$ asi lo razone, que el caso presentaba serias dudas de hecho o de derecho»;

la Administración, sin matices. Porque lo cierto es que, aunque sean las menos, en ocasiones el recurso contencioso-administrativo revela que no es la Administración la parte más débil en la contienda o que en la razón del desencuentro anida un debate complejo que se ha gestionado seriamente en vía administrativa. Cabe, en definitiva, que los motivos que llevan a moderar el alcance de la condena en costas procesales resulten trasladables a la Administración en un caso dado.

De ser así, conste que la moderación de las costas procesales de la Administración no constituye una lesión del derecho fundamental a la tutela judicial efectiva del particular vencedor. Es de recordar en este sentido que el resarcimiento íntegro de los gastos del proceso en caso de victoria no ha sido considerado un correlato extraíble de nuestro art. 24 de la CE. Así lo tiene bien establecido el TC —véase la importante STC 131/1986, de 29 de octubre, que es la que marcó la línea general, y, de forma más específica, el ATC 119/2008, de 6 de mayo.

Teniendo en cuenta esta doctrina constitucional, se deduce que no cabe oponerse a la limitación de las costas procesales de la Administración ex art. 139.4 de la LJCA con base en una suerte de derecho del particular vencedor al resarcimiento íntegro de los gastos del proceso. Así de contundente respondía el TS a una alegación de este orden: «Las partes del proceso pueden contratar los servicios de los profesionales que libremente elijan y convenir los honorarios que consideren procedentes, en un ámbito de libre concurrencia y sin sujeción a sistemas de arancel. Pero sin ignorar que la Ley aplicable, en el caso de que proceda la condena en costas, no asegura el pleno reintegro de la cantidad satisfecha por el referido concepto» (ATS de 8 de julio de 2009, JUR 2009/350342) 
«salvo que el órgano jurisdiccional, razonándolo debidamente, las imponga a una de ellas por haber sostenido su acción o interpuesto el recurso con mala fe o temeridad»...).

Nada similar aparece en el tenor literal del art. 139.4 de la LJCA. Por tanto, ni se señalan los motivos ni se exige que se seńalen después por el juez administrativo. Tal vez se estime que el planteamiento resulta acertado en la medida en que proporciona al órgano jurisdiccional un amplio margen de decisión a la hora de identificar en qué casos resulta procedente limitar la condena en costas, lo cual, claro está, viene de molde para caminar en un terreno tan irregular como es el que abarca la justicia administrativa ${ }^{21}$. La flexibilidad en esta materia ofrece ventajas; ventajas que mandando el vencimiento y su rigidez natural son, más si cabe, convenientes. Sin embargo, una cosa es que la letra de la ley sea maleable y otra bien distinta la ausencia de todo amarre. En aras de estatuir una potestad flexible no hace falta sacrificar sin más el valor de la precisión. Lo uno no está reñido con lo otro. Y he aquí que la falta absoluta de indicaciones en la ley se antoja más un descuido que una necesidad.

B. La ley no es ciertamente en este caso acicate para la motivación. Pero el caso es que tampoco la jurisprudencia ha avanzado mucho más. En general, cabe afirmar que el juez administrativo se viene recostando en la anchura de la norma para movilizar este poder con pocas explicaciones. Muchas veces solo se invoca el precepto acompańado de una categórica indicación de que «se considera procedente en este supuesto» limitar las costas. Esta motivación de perfil tan bajo se enmarca, por lo demás, en un contexto, el de las costas procesales, en el que, desde hace mucho, se ha instalado la tendencia a no exponer, sintetizar en extremo o, simplemente, dar por supuesto - el vencimiento y su mecánica automática han empujado, claro es, en esta direcciónel razonamiento que lleva a una determinada solución. Una devaluación de la motivación inquietante a la que, solo discretamente, el TC ha puesto algún que otro freno ${ }^{22}$.

21 Y no solo eso. En mi opinión, este tipo de válvulas que abren un hueco para ajustar la universalidad de las reglas despejan mucho el camino a la hora de interpretar las normas con arreglo a la realidad social de cada momento. Tratándose de un tema con un evidente trasfondo económico, como es el de las costas procesales, la influencia de la crisis económica podría asimismo dejar huella en la andadura del art. 139.4 de la LJCA.

22 Una exposición más detenida al respecto en Cierco Seira (2016: 120-127).

No resulta extraño, en efecto, que la praxis en torno al art. 139.4 de la LJCA se haya contagiado de la debilidad reinante en la motivación de las costas — responsable en parte del deterioro y desprestigio del canon de la temeritas, proclive al desuso-. 
Siendo esto así, es evidente el peligro de que la parte perjudicada vea en el uso del art. 139.4 de la LJCA un ejercicio de voluntariedad por parte del juzgador, es decir, que en lugar de una llamada al prudente arbitrio lo tenga por un alea generador de frustración. Lo cual sirve a la postre en bandeja la crítica a la inseguridad jurídica y a la desigualdad en la aplicación de la ley. El acecho de la arbitrariedad se agudiza ${ }^{23}$.

En cualquier caso, aunque el panorama aparezca dominado por esa relajación a la hora de invocar el poder de limitación de la condena en costas, no faltan tampoco los pronunciamientos en los que, siquiera sea con un cierto convencionalismo, se da cuenta de algunas razones más concretas. Veámoslo a continuación.

\section{LAS JUSTIFICACIONES MÁS CORRIENTES QUE OFRECE EL JUEZ ADMINISTRATIVO: EL TRABAJO DE LA PARTE VENCEDORA, LA ENTIDAD DE LA CAUSA Y LA CONCURRENCIA DE VENCEDORES}

Si nos adentramos en el proceloso mar de las costas procesales advertiremos la presencia de algunas líneas argumentales que otorgan algo más de contenido a la simple invocación del poder de limitación y del precepto que le proporciona sostén legal. La identificación de esas líneas argumentales resultaría sin duda más acabada y consistente si contásemos con una estadística judicial que incluyera la medición de ciertos extremos atinentes a las costas procesales en la justicia administrativa: si hay condena o no; a qué parte; si se han limitado y, en su caso, a qué cuantía, etcétera ${ }^{24}$. Por desgracia, no la hay.

Sin embargo, conviene no perder de vista que, fuera de la necesidad de reforzar en general la motivación de este apartado, hay en el art. 139.4 de la LJCA un grado muy fuerte de intensidad en la concesión de arbitrio, cosa que debería ir acompañada de un correlativo esfuerzo en la explicación. Es un lugar común en los estudios sobre el arbitrio judicial la significación de la motivación como elemento clave para evitar caer en la arbitrariedad. Véase la interesante exposición de M. Segura Ortega (2006), Sentido y límites de la discrecionalidad judicial, Madrid: Editorial universitaria Ramón Areces (págs. 75-92).

23 Y es sabido que el comportamiento arbitrario de todos los poderes públicos está tajantemente proscrito. Grabado lo hallamos en el art. 9.3 de la CE.

24 Importa mucho adquirir conciencia de la importancia de la estadística y otras ciencias sociales a la hora de abordar ciertos problemas jurídicos. Reflexión en la que se viene insistiendo con razón —entre otros, J. Ponce Solé (2014), «Ciencias sociales, Derecho Administrativo y buena gestión pública. De la lucha contra las inmunidades del poder a la batalla por un bueno gobierno y una buena administración mediante un diálogo fructífero", Gestión y análisis de politicas públicas, 11, págs. 1-20-y que fue uno de 
De forma que, ausente este acervo estadístico, hay que renunciar a cualquier pretensión de completitud y asumir una posición más modesta. Lo que se expone a continuación son algunas consideraciones producto de un ejercicio de lectura y meditación a la vieja usanza; hecho a partir de catas, más o menos profundas, en los distintos niveles de la planta de nuestra jurisdicción contencioso-administrativa.

A. Uno de los motivos estrella viene dado por la actividad desplegada por la parte vencedora. Son muchos los pronunciamientos judiciales en los que se estima que, en razón de dicha actividad, es procedente establecer un límite en la condena en costas.

El mensaje que lanza el juez administrativo en estos casos es tan elemental en su formulación como chocante en su valoración última. Salta a la vista que, generalmente, detrás de la invocación de la "actividad desplegada» - u otros sintagmas parecidos: «actuación profesional desarrollada ${ }^{25}$, "dedicación requerida» ${ }^{26}$, "contenido de los escritos» ${ }^{27}$, "trabajo y esfuerzo desplegado ${ }^{28}$, "estudio que ha merecido» ${ }^{29}$, "utilidad del escrito» ${ }^{30}$, y así siguiendo - late la consideración de que la defensa de la postura que se ha llevado finalmente la palma ha sido sencilla y no ha requerido de particulares esfuerzos ${ }^{31}$. Imagen de la que son paradigma las segundas instancias toda

los hilos conductores del I Seminario Interuniversitario de Teoría y Método del Derecho Público, celebrado en Valencia el 31 de mayo de 2013.

25 Véase, por ejemplo, la STSJ del País Vasco de 14 abril de 2015 (recurso 352/2013).

26 Utilizado, entre tantas, por la STS de 16 de julio de 2014 (recurso 3106/2013).

27 Motivo que aparece, por ejemplo, en la STSJ de Madrid de 11 de mayo de 2015 (recurso 347/2014).

28 Como se señala en la STSJ de Galicia de 15 de junio de 2016 (recurso 306/2015).

29 Así se indica en la STSJ de Galicia de 1 de junio de 2016 (recurso 128/2016).

30 Empleado como motivo en la STS de 19 de septiembre de 2016 (recurso 2455/2015).

31 Demostrativa de ello, entre tantas, la STS de 26 de julio de 2016 (recurso 3492/2015). Se limitan en este caso las costas procesales a quinientos euros «atendiendo a la índole del asunto y a la actividad desplegada por la parte recurrida en su oposición al recurso", remitiendo, por más seńas, a lo relatado en los antecedentes de hecho. Al acudir allí descubrimos cómo la referencia a la actividad desplegada esconde más bien un reproche: «Recibidas las actuaciones en esta Sección Tercera, por diligencia de ordenación de 5 de febrero de 2016 se dio traslado del escrito de interposición a la parte recurrida para que formalizase su oposición, lo que llevó a cabo la Abogacía del Estado mediante escrito presentado el 15 de febrero de 2016 en el que, sin aludir a los hechos y circunstancias del caso presente y sin referirse a los motivos de casación aducidos por el recurrente, se limita a exponer unas consideraciones de carácter general sobre los requisitos necesarios para el otorgamiento del asilo. Y sin haber aducido en 
vez que se parte de un debate ya definido al que se busca dar, legítimamente, alguna vuelta de tuerca ${ }^{32}$. Aunque no se diga así expresamente se colige que la parte vencedora en vía de recurso acaso no haya tenido que emplearse a fondo, pudiendo servirse de elementos ya expuestos en niveles previos. Y no en vano hallamos una legión de sentencias en las que el poder que nos ocupa se invoca por parte del Tribunal Supremo al fallar la casación con base, precisamente, en la "actividad desplegada». Con todo, insisto en que no es un motivo que se emplee exclusivamente en el marco de la casación. También aparece con frecuencia en apelación ${ }^{33}$. Lo mismo que, en fin, en la primera instancia ${ }^{34}$.

El principal escollo de este motivo trae causa del desplazamiento del centro de gravedad a que da lugar en la medida en que apunta, básicamente, a la labor de defensa del abogado, lo que puede llevar al discurso a enfilar un camino tortuoso. Tortuoso toda vez que se presta al recelo corporativo respecto del juicio, cuantificado a la baja, de una actividad que es de naturaleza intelectual, que se proyecta sobre un caso dado y que no parece tener en cuenta la concurrencia de méritos o de otros factores. Asimilar la idea de que la limitación de las costas se debe a que el esfuerzo fue liviano puede desconcertar a quien ha cargado con la llevanza de la defensa, como es lógico. Y no tanto tal vez por la falta de idoneidad del criterio en sí —al final y al cabo la dedicación, como tal, no viene a desencajar con los criterios tasadores al uso- , sino por la tosquedad de su formulación y de la forma con que se viene a hacer presente: a través de una valoración del juzgador in ictu oculi; en un lugar y momento extraño, es decir, fuera del trámite de tasación, que se antoja por lo demás el escenario natural para ello; y casi siempre sin desgranar, siquiera mínimamente, el porqué.

Pero insisto en que, sobre todo, la alusión a la actividad desplegada, presentada sin matices como justificante de la limitación de las costas, desvía la atención de lo que debería ser realmente crucial al poner en marcha el art. 139.4 de la LJCA: la necesidad de minorar la condena en costas para que el

su escrito ninguna causa de inadmisión del recurso, el escrito del Abogado del Estado termina solicitando que se inadmita (sic) o, subsidiariamente, se desestime el recurso de casación y se impongan las costas al recurrente».

32 Por supuesto pueden concurrir otro tipo de factores, como la similitud con otro asunto ya defendido, la escasa dificultad del tema, el hecho de tratarse de un asunto de una serie masiva, etcétera.

33 Sirva de ejemplo la STSJ de Cataluña de 23 de marzo de 2015 (recurso 300/2014).

34 Valga como botón de muestra la STSJ de Galicia de 15 de junio de 2016 (recurso 306/2015). 
impacto económico de la derrota sobre la parte vencida no represente un obstáculo excesivo en su paso por la justicia.

B. Otra de las razones más repetidas se contrae a la entidad del asunto. Claro que esta referencia a la entidad puede ser sinónimo luego de muchas cosas.

Cabe, de entrada, que el juez administrativo tome en consideración la cuantía del pleito. Ya sea porque se trate de un litigio millonario y estime procedente limitar el tope de las costas procesales para que no se disparen ${ }^{35}$; o bien, con la misma intención, porque, siendo el pleito de mínimos, la reducción de la factura de las costas sea tenida como un correlato producto del equilibrio interno del proceso $^{36}$. La cuantía del pleito es, pues, argumento reversible y lo cierto es que resultaría relativamente fácil transitar esta senda si la determinación de la cuantía del recurso contencioso-administrativo fuese extremo más o menos pacífico. Sin embargo, en la práctica no lo es. De hecho, estamos ante uno de los puntos débiles del proceso contencioso-administrativo $^{37}$. De manera que al mover la palanca del art. 139.4 de la LJCA con base en el argumento de la cuantía del pleito cabe que el juez administrativo tenga en mente las dificultades habidas a la hora de establecer dicha cuantía y acaso

35 Que es justamente lo que ocurría en el asunto fallado por la SJCA núm. 5 de Bilbao de 2 de septiembre de 2013 (recurso 429/2011): la cuantía del recurso impulsado por una asociación contra un proyecto de urbanización superaba los cinco millones de euros. Esa circunstancia devino en la razón de activar la facultad de limitación del art. 139.4 de la LJCA.

36 Una muestra elocuente de esta línea de razonamiento la ofrece la STSJ de las Islas Canarias de 27 de febrero de 2007 (recurso 1053/2002): «En el presente caso, aunque no se aprecia mala fe o temeridad en la Administración demandada, es claro que, dado el importe de la devolución reclamada, 844,73 euros, la no imposición de costas supondría hacer perder su finalidad al recurso, por resultar más oneroso el acceso al recurso que el propio importe de la indemnización reclamada, pero eso sí, con aplicación de lo dispuesto en el apartado 3 del citado precepto, conforme al cual: «3. La imposición de las costas podrá ser a la totalidad, a una parte de éstas o hasta una cifra máxima», por lo que en evitación de cuantías excesivas procede también limitar la cuantía de las costas a la cantidad total de 300 euros».

Casos igualmente gráficos al respecto ofrecen las SSTSJ de Madrid de 4 de mayo de 2007 (recurso 687/2003) y 3 de mayo de 2016 (recurso 927/2015).

37 Los efectos negativos que las imperfecciones y debilidades en la fijación de la cuantía del proceso contencioso-administrativo son capaces de trasladar a las costas procesales son nítidos. Extremo sobre el que con resolución viene insistiendo, entre otros, S. González-Varas Ibánez (2012), Tratado de Derecho Administrativo, t. III, Madrid: Civitas, 2a ed. (págs. 499-500 y 1026-1028). 
la imperfección de su desenlace — tantas veces por medio del «comodín» de la cuantía indeterminada- y los desajustes que ello puede provocar, de no utilizarse el poder de limitación, en las costas procesales ${ }^{38}$.

La apelación a la entidad del asunto puede responder, por otra parte, a la naturaleza del pleito y de las pretensiones en él sustanciadas, contando con que, como todos sabemos, la justicia administrativa acoge en su interior materias tocantes a bienes jurídicos sensibles. Huelga decir que no existe catalogación positiva alguna, pero no es difícil en todo caso reconducir a este género ideal una parte importante de la extranjería ${ }^{39}$; o, por poner otro ejemplo elocuente, de la responsabilidad patrimonial con daños personales graves ${ }^{40}$. Que el juez administrativo decida limitar las costas procesales del particular vencido en este tipo de lances deja entrever, bien apurada la cosa, un intento por matizar la dureza de la condena en costas en escenarios donde el debate reviste connotaciones y compromete a bienes e intereses que trascienden lo estrictamente patrimonial y donde es visible que el justiciable ocupa una posición que le hace especialmente vulnerable frente al coste del proceso ${ }^{41,42}$.

38 La SJCA núm. 1 de Santander de 14 de marzo de 2016 (recurso 367/2015) nos ofrece un episodio bien demostrativo. Adviértase el razonamiento que se emplea para hacer uso del poder de limitación: «No obstante, en el presente caso, por el contenido de la pretensión debe fijarse una cuantía indeterminada pero el pleito ha consistido en una mera discusión jurídica en torno a un punto de un acuerdo municipal para la atribución de una tarea concreta de trabajo, por lo que procede hacer uso de la facultad del art. 139.3 LJ y concretar el importe de las posibles costas que se giren de modo que, en total, no podrán exceder de 800 euros por todos los conceptos regulables».

39 El de la extranjería es uno de los ámbitos sobresalientes en el uso del poder de limitación de las costas procesales. Véase, ex multis, la STSJ del País Vasco de 17 de octubre de 2012 (recurso 183/2010).

40 Ámbito en el que se encuadra la STSJ de Madrid de 21 de diciembre de 2015 (recurso 5/2011).

41 Recomiendo al lector la lectura de la STC 124/2015, de 8 de junio. Aunque el meollo del asunto atañe al beneficio de justicia gratuita, el episodio arranca con una reclamación de responsabilidad patrimonial, a raíz de una caída en la vía pública, que es desestimada por silencio. Interpuesto a continuación recurso contencioso-administrativo, el particular pierde y es condenado en costas a la cantidad de 28.128,41 euros. Esta deuda, sumada a la tasa judicial (867,83 euros) y a su frágil situación patrimonial, le llevan a solicitar el beneficio de justicia gratuita para poder recurrir en apelación. Vemos, pues, cómo el paso por la primera instancia de lo contencioso-administrativo y la condena en costas provocaron aquí un evidente empobrecimiento que, como se cuidó de señalar el TC, debió ser tenido en cuenta por la Comisión de Asistencia Jurídica Gratuita.

42 Lo cual, a su vez, refuerza la idea de que el comportamiento de las costas procesales tiende a modularse superando el corsé del vencimiento en función de la naturaleza de 
Sin cambiar de tercio, la entidad se viste otras veces de complejidad o, al revés, de sencillez del tema - lo cual conecta fácilmente, a su vez, con el argumento anterior de la actividad desplegada ${ }^{43}$.

Resulta, en suma, que la entidad del asunto puede ir ligada acaso a la cuantía del pleito, a su naturaleza o al grado de complicación de la controversia. Pero es de fuerza señalar que también hay pronunciamientos en los que esta expresión constituye poco más que una muleta con la que denotar la aplicación de la facultad de limitación a la luz de las circunstancias particulares del caso de turno. La entidad del asunto se transforma entonces en un simple distintivo de casuismo.

C. Hay, en fin, una tercera razón que aparece con frecuencia y que tiene que ver esta vez con la singularidad del litisconsorcio pasivo en lo contenciosoadministrativo y la eventualidad, nada excepcional, de que la defensa del acto, disposición o actuación controvertidos convoque a otros sujetos aliados de la Administración que van a actuar con la condición de parte procesal plena - $\mathrm{y}$, por tanto, devengando costas procesales, a diferencia de los antiguos coadyuvantes $^{44}$ - La ilustración es sencilla. Basta pensar en ámbitos como la

la contienda administrativa y de los intereses que en ella se ventilan. De gran ayuda resulta justamente la línea de trabajo, basada en el estudio por sectores, seguida en el Informe sobre la Justicia Administrativa, dir. por S. Díez Sastre. Muchas son las conclusiones de interés en lo que atañe al funcionamiento del sistema de costas procesales, pero no me resisto a destacar una que se contiene en el Informe de 2016 y que afecta a la responsabilidad patrimonial: « [...] sugieren [los datos] que los tribunales se alejan del criterio del vencimiento en un número importante de casos, a pesar de la generalización de este criterio a raíz de la aprobación de la Ley 37/2011. En segundo lugar —y en lo que aquí interesa-, los datos sugieren que los tribunales son más propensos a eximir al recurrente de la necesidad de hacerse cargo de las costas del procedimiento cuando su reclamación se produce frente a algún tipo de actividad material o inactividad que cuando se produce frente a la actividad formal de la Administración» —F. Pastor Merchante (2016), «Análisis de la litigiosidad administrativa y contencioso-administrativa en materia de responsabilidad patrimonial», en Informe sobre la Justicia Administrativa 2016, Madrid: Universidad Autónoma de Madrid, págs. 177-216 (pág. 213).

43 «En este caso, se valora que no estamos ante un supuesto excesivamente complejo [...] de modo que se limitan las costas procesales por todos los conceptos al importe de 3.000 euros» (STSJ de Extremadura de 26 de mayo de 2016, recurso 1/2016). En la misma línea, véanse la SJCA núm. 1 de Ciudad Real de 30 de junio de 2016 (JUR 2016\171461) y la SJCA núm. 2 de Ciudad Real de 19 de julio de 2016 (JUR 2016\171707).

44 La diferencia entre los actuales codemandados respecto de los antiguos coadyuvantes es muy nítida en este punto. Es de recordar simplemente que, según preveía el art. 131.2 de la LJCA de 1956: «la parte coadyuvante no devengará ni pagará costas más 
responsabilidad patrimonial (contratistas, compañías de seguros...), la función pública (concursantes...), el urbanismo (propietarios, vecinos...) o la contratación (competidores...). Codemandados cuyo concurso, sobre ello, puede ser aun inesperado en el sentido de que traiga causa su comparecencia de la interpelación hecha por la Administración a través del trámite de emplazamiento de interesados (ex art. 49 de la LJCA).

Pues bien, la presencia de codemandados, especialmente allí donde su número es significativo, constituye un factor que el juez administrativo pone en ocasiones en la balanza a la hora de limitar la condena en costas procesales. Actúa de esta suerte el art. 139.4 de la LJCA a modo de cláusula moderadora de la multiplicación en cadena de las litis expensas ${ }^{45}$. Orientación que, por lo demás, se alinea con lo que pasa por ser un criterio común colegial en la tasación de las minutas de los abogados ${ }^{46}$.

Como ha podido verse, aunque estas tres razones introduzcan algo más de luz en la explicación de la limitación de las costas procesales, están todavía lejos de despejar los numerosos claroscuros acerca de la activación de esta potestad. De hecho, ninguna de las razones presenta unos perfiles acabados. Casi siempre hace falta recurrir al cuerpo de la sentencia en busca de pistas que nos aclaren el significado último de la «actividad desplegada» o de la «entidad del asunto»; locuciones que, por sí solas, sin ayuda del contexto, dicen más bien poco $^{47}$.

que por razón de los recursos o incidentes que ella promueva con independencia de la parte principal».

45 A tal objeto, el juez administrativo establece un tope que se aplicará para cada uno de los vencedores. Véanse, a título ilustrativo, las SSTS de 8 de octubre de 2013 (recurso 315/2011) y 25 de octubre de 2013 (recurso 823/2011); o la STSJ de Galicia de 25 de septiembre de 2014 (recurso 4404/2012). En la primera de ellas, sin ir más lejos, el actor tenía enfrente a la AGE y hasta seis codemandados.

46 El problema de la pluralidad de demandados no es menor y tiene, además, múltiples ribetes en la justicia administrativa. En lo que aquí importa, la multiplicación de las costas procesales a que viene a dar lugar muy bien puede convertirse, en determinados escenarios especialmente aptos para que se produzca este fenómeno, en un factor de disuasión en el acceso a la justicia — y, por ende, de empobrecimiento en la fiscalización de la actividad administrativa correspondiente.

47 Añadiré que incluso cuando se yuxtaponen la motivación resultante sigue siendo débil. La mixtura de motivos, lejos de fortalecer la explicación, la debilita y hace más confusa la razón de limitar. 


\section{LAS MODALIDADES Y EL ALCANCE DE LA MODERACIÓN DE LAS COSTAS PROCESALES}

\section{LAS MODALIDADES EN QUE PUEDE CONCRETARSE LA MODERACIÓN: LA CONDENA PARCIAL Y/O HASTA UNA CIFRA MÁXIMA}

La activación de la facultad de limitación recogida en el art. 139.4 de la LJCA no afecta, como ya se hizo notar, a la existencia de la condena en costas procesales que, de hecho, presupone. La eficacia de este singular poder conferido al juez administrativo tiene que ver con la atenuación y moderación del contenido de la condena. Pues bien, a tal objeto se arbitran en abstracto dos posibles vías.

A. De una parte, cabe que la que condena en costas se atempere transformándose en una suerte de condena parcial. En efecto, conforme a lo previsto en el tenor literal del precepto, es dado que el juzgador limite la imposición de costas «a una parte de éstas». Cumple señalar, para inteligir adecuadamente esta opción, que las costas procesales no tienen un contenido institucional inalterable. Antes al contrario, se trata de una categoría de configuración abierta que el legislador define en cada momento con amplia libertad. En la actualidad, el listado de gastos del proceso que vienen a integrar las costas se halla consignado en el art. 241.1 de la LEC. Si enlazamos esta circunstancia con el poder que nos ocupa resulta que la moderación puede articularse descontando ciertas partidas por considerar que resulta oportuno liberar al condenado de la necesidad de sufragar en su integridad determinados gastos del proceso; o, lo que es lo mismo pero visto ahora desde otro ángulo, circunscribiendo la condena solo a algunas partidas. Gracias al señalamiento de tal o cual partida el juez administrativo puede, por lo demás, otorgar un tinte concreto al ejercicio del poder de limitación. Pensemos, sin ir más lejos, en la vinculación que cabe trabar entre la facultad de limitación y las tasas judiciales ${ }^{48}$.

48 Cuando la limitación de las costas procesales beneficia a la Administración vencida conviene reparar en si el particular tuvo que abonar una tasa judicial para accionar $y$, de ser así, parece sensato preconizar que la devolución de la tasa judicial sea íntegra y que, en consecuencia, cuide el juez administrativo de dejar esta partida fuera de toda limitación. Es esta una orientación de la que encontramos claros exponentes en la labor del TSJ de Madrid. Véanse, a título de ejemplo, las sentencias de 20 de octubre de 2014 (recurso 2028/2013), 11 de mayo de 2015 (recurso 1313/2014) y 18 de mayo de 2015 (recurso 1344/2014).

Por el contrario, si el condenado en costas es el particular, resultaría oportuno, a mi modo de ver, que el juez administrativo tomara en consideración al hacer balance 
B. No ha sido esta, sin embargo, la modalidad más empleada. Se ha impuesto, por el contrario, una segunda opción, recogida también en el tenor liberal del art. 139.4 de la LJCA, que pasa por imponer las costas «hasta una cifra máxima». La condena hasta una cifra máxima supone, ni más ni menos, el establecimiento de un tope, de tal manera que la tasación que habrá de practicarse después nunca podrá rebasar la cantidad señalada.

Que en líneas generales el juez administrativo se haya inclinado por esta segunda opción no deja de ser sorprendente. A primera vista, cuando menos, se diría que fijar una cifra máxima representa de suyo una operación más delicada y comprometida que seleccionar unas concretas partidas, tanto más si tenemos en cuenta que la cantidad ha de cifrarse in ictu oculi, sin tener delante el resultado de la tasación venidera.

Sea como fuere, la disyuntiva no solo es cosa de mayor o menor compromiso. Es de notar que ambas modalidades, aun conducentes a un mismo resultado moderador, hacen que el uso del poder adquiera un distinto cariz. La limitación de partidas, si bien se mira, da razón de la voluntad de corregir el reparto de los gastos procesales que han tenido lugar a fin de que algunas partidas recaigan exclusivamente sobre la parte que ha sido vencida en pleito y condenada en costas. El establecimiento de una cifra máxima, por su parte, apunta derechamente a la dimensión cuantitativa, a la factura, por así decir. Se busca, sin rodeos, que el importe de las costas procesales no supere una cuantía que se estima razonable en vista de las circunstancias del pleito.

\section{EL ENIGMA DE LA CIFRA MÁXIMA. LAS LUCES DE LOS CRITERIOS INTERNOS Y LAS SOMBRAS DE LA INCOHERENCIA DEL CONJUNTO}

Aclarado que, por lo común, nuestros órganos judiciales se decantan por dar una cifra máxima cuando hacen uso del art. 139.4 de la LJCA, la pregunta que de inmediato sale al paso es la relativa a cuál es y cómo se obtiene esa cifra máxima.

Pues bien, estamos, simplemente, ante un enigma. Lógicamente, el empleo de esta cláusula no ha llevado a modelar un límite económico de validez universal. Se trata de una potestad cosida al proceso y a merced, pues, de las circunstancias particulares de cada asunto. Está llamada a aplicarse caso por caso y ello por fuerza ha de traducirse en cuantías distintas.

El problema, sin embargo, no radica en el componente casuístico, que cae por su propio peso. Lo preocupante y desconcertante es la ausencia de jus-

final del impacto de la derrota y de la condena en costas el hecho de haber abonado ya una tasa judicial y su importe como posible razón para limitar el alcance de aquellas. 
tificación en cuanto a las razones que llevan a fijar tal o cual cantidad. Una vez más, asistimos al fenómeno de relativización de la motivación, que es santo y seña de la imposición de costas y que se manifiesta en resoluciones judiciales donde se fija directamente una cifra máxima sin dar cuenta de su razón. Es del todo habitual, en efecto, que no se explique el origen y el método de cálculo utilizado para dar con el tope establecido, lo cual, amén de llamativo, desconcierta contemplado desde fuera de los estrados.

Ciertamente, la lectura continuada de pronunciamientos que contienen una moderación de este tenor revela en ocasiones la presencia de patrones en el sistema y, sobre todo, de ciertas pautas en el seno interno de los órganos jurisdiccionales. Patrones y pautas que dejan entrever un poso de coherencia, especialmente interno; una idea de repetición, de serie.

a. Con respecto a los que podríamos denominar patrones sistémicos, su presencia es clara, si bien, de elemental en su formulación, pueden parecer apuntes menores. Es fácil descubrir, por ejemplo, que se sigue una regla según la cual las cifras máximas aumentan a medida que se sube en la escalera judicial. Así, la tónica es que los límites establecidos en la primera instancia sean más bajos que los aplicados en la apelación o casación. Se aprecia, asimismo, que ciertas materias resultan especialmente propicias de cara a la disminución del límite máximo. La extranjería constituye uno de los terrenos más elocuentes y donde se registran los topes más bajos en este sentido.

b. La coherencia en el manejo del art. 139.4 de la LJCA se apoya, en lo esencial, en la existencia de pautas domésticas en el seno de cada órgano jurisdiccional. No hay duda de que si se sigue la producción de los distintos tribunales es posible reconocer una serie de "tics» que se repiten y que hacen ver que hay un criterio interno. A veces en forma de usus fori de una sala o sección, otras moviéndose en el terreno más personal del juzgador de turno. Aunque por lo general no se explicitan tales pautas, de tanto en tanto su existencia salta a las páginas de la sentencia y se nos revela sin ambages: «para la fijación de la expresada cantidad se tienen en cuenta los criterios seguidos habitualmente por esta Sala en atención a las circunstancias del asunto y a la dedicación requerida para formular la oposición [...]» ${ }^{49}$. El rastro de esta tabulación doméstica de la cifra máxima de las costas procesales no solo es reconocible en la labor pretoriana del Tribunal Supremo. De su existencia en los Tribunales Superiores de Justicia y aun en los Juzgados de lo Contencioso-Administrativo hay también constancia explícita: «Para la fijación de la expresada cantidad se tienen

49 El entrecomillado procede de la STS de 16 de julio de 2014 (recurso 3106/2013). Más recientemente, véase, entre muchas, la STS de 20 de julio de 2016 (recurso $1511 / 2015)$. 
en cuenta los criterios seguidos habitualmente por este Tribunal en razón de las circunstancias del asunto y de la dificultad que comporta" ${ }^{50}$; "según criterio mantenido por los juzgados de lo contencioso-administrativo de esta ciudad [Ourense] y atendiendo a la naturaleza del litigio [...]» ${ }^{51}$.

Con todo, tengo para mí que la constatación de la existencia de pautas y patrones que denotan una cierta uniformidad en la aplicación del art. 139.4 de la LJCA es un consuelo que sabe a poco. Se impone en líneas generales la sensación de incertidumbre y de que el signo de la activación de la facultad de limitación puede al cabo cambiar en cualquier momento; que es sumamente mudable y que está expuesto a un sinfín de eventualidades difíciles de ponderar de antemano, al tiempo de decidir si ir a juicio, comenzando por los vaivenes en las plazas de los distintos órganos jurisdiccionales, no digamos ya si hablamos de los juzgados de lo contencioso-administrativo, de carácter unipersonal, donde el componente intuitu personae se multiplica exponencialmente ${ }^{52}$.

Por más que apreciemos surcos de uniformidad en el terreno, no puede negarse, en suma, que las pautas y patrones apuntados están lejos de proporcionar al sistema un rumbo certero y previsible.

En primer lugar, es de advertir que las cifras no son uniformes y que el importe varía. Quiere eso decir que no hay una tabulación fija en la primera instancia, otra en la apelación y otra, en fin, en la casación. De hecho, ni siquiera en el seno de cada órgano jurisdiccional se maneja un solo techo. Los

50 Acúdase a la STSJ de Andalucía de 30 de mayo de 2016 (recurso 92/2014).

51 Así se pronunciaba el Juzgado de lo Contencioso-Administrativo núm. 1 de Ourense en su Sentencia de 23 de octubre de 2015 (RJCA 2016/44). Criterio que, a lo que parece, continúa vigente. Véase, del mismo Juzgado, la Sentencia de 3 de febrero de 2016 (recurso 231/2015).

52 Es, en efecto, terreno abonado a la aparición de criterios particulares de cada juez, expresiones al fin de una manera de concebir la equidad. Demostrativo de ello es, por ejemplo, este fragmento extraído de la SJCA núm. 1 de Huesca de 21 de febrero de 2014 (JUR 2014/79445): «Permite el artículo 139.3 que la imposición de costas lo sea hasta una cifra máxima, y es criterio de este Juzgador que las costas queden razonablemente limitadas a un $4 \%$ de la cuantía del litigio, dentro de una horquilla absoluta de 400 a 4000 euros. Relacionando este criterio con el Artículo 394.3 de la Ley de Enjuiciamiento Civil, el monto máximo para pretensiones de cuantía indeterminada será de 720 euros».

Fórmula del $4 \%$ de la cuantía. Criterio personal que contrasta con otros. Véase así la fórmula de la tercera parte —inspirada en el proceso judicial civil_ por la que se inclina otro juzgador en la SJCA núm. 4 de Bilbao de 30 de octubre de 2013 (recurso 175/2012): «[...] de acuerdo con lo dispuesto en el apartado 3 del artículo 139 de la LJCA, este magistrado considera que procede hacer la mencionada imposición solamente hasta la cifra máxima de la tercera parte de la cuantía del proceso». 
patrones internos reflejan más bien la existencia de horquillas que luego se ajustan en función de ciertas variables - variables que, por lo común, permanecen ocultas-. El espacio o la distancia que vienen a cubrir estas horquillas no es menor $y$, por remate, siempre queda espacio para el apartamiento puntual, hecho que, aun siendo consustancial a esta potestad de signo casuístico, agudiza la impresión general de incertidumbre.

Tenemos, en segundo término, el problema de la cognoscibilidad de las pautas allí donde se siguen. Ya se ha dicho que la explicación no suele quedar consignada en la sentencia. En su defecto, algunos órganos jurisdiccionales, conscientes de esta situación y de las críticas que genera, han decidido dar un paso adelante, consensuando una suerte de código doméstico que ha venido a plasmarse en acuerdos gubernativos — de la Sala o de la Junta de Jueces-; una suerte de, por así decir, ejercicio de autorregulación a cuya virtud se vienen a obtener parámetros de actuación, así sean puramente orientativos, que buscan unificar los criterios. La medida es, sin duda, meritoria. Otra cosa es que sean este tipo de acuerdos el medio idóneo para vehicular una solución suficiente cuando resulta evidente que es labor que corresponde al legislador ${ }^{53}$.

Y resta aún la principal objeción a realizar. Porque la coherencia, en el mejor de los casos, se alcanza en la labor de un juzgado o tribunal considerado en singular. ¿Qué hay, sin embargo, de la comparación con los demás? Sencillamente, una miscelánea que se resiste a la sistematización.

La inconexión entre los diferentes grados e instancias es chocante. Por más que se reconozca una graduación progresiva en la cifra que se establece como límite, se trata de una línea de trazo grueso que, sobre ello, deja fuera a los casos en los que no se hace aplicación de la facultad limitadora. Es un lugar común en este sentido significar que mientras que en la casación la moderación de las costas es la tónica no se conoce tal nivel de generalización en la primera instancia de lo contencioso-administrativo ${ }^{54}$. De igual forma,

53 Por cierto que la localización de estos acuerdos y el acceso al contenido de los mismos no es sencillo. Solo en contados casos se ha hecho un esfuerzo por publicitarlos de forma ordenada en Internet.

54 La anomalía comparativa a que puede dar lugar todo ello: que un recurso contencioso-administrativo de poca complejidad en primera instancia devengue un importe en costas superior a un recurso de casación. Derivación sobre la que ya se ha puesto el acento críticamente: «Esta potestad de limitar las cuantías está dando lugar a una disparidad de criterios entre los distintos Juzgadores (exceptuando el TS que mantiene cierta uniformidad) que los está convirtiendo en auténticos reinos de taifas, llegándose a la paradoja que unas costas impuestas sin limitación en un Juzgado Unipersonal de lo Contencioso pueden tasarse muy por encima de los 6000 euros, máxima que hoy por hoy fija el TS al rechazar las casaciones» —G. García Weil (2016), «A vueltas con 
es de sobra conocido el contraste entre el apego que el TS denota en cuanto al empleo de esta potestad y la posición reticente que en cambio mantiene al respecto la Audiencia Nacional ${ }^{55}$.

La falta de cohesión también se da, por supuesto, en el plano horizontal. Baste, si no, dar un simple vistazo a las cifras que manejan los Tribunales Superiores de Justicia para caer en la cuenta de la diversidad y de la fragmentación a que conduce la puesta en práctica del art. 139.4 de la LJCA. Los límites aplicados de manera habitual a las apelaciones varían sensiblemente en función del Tribunal Superior de Justicia de que se trate. Se dirá que el cotejo es fragilísimo y, sin duda, lo es — vendría aquí de molde un conocimiento estadístico del suelo que se pisa-. Pero no pretendo en absoluto dar por contrastado un gap económico en la apelación entre Tribunales Superiores de Justicia. Solo poner de relieve la facilidad con la que pueden surgir divergencias por razón del territorio que no cuadran con la lógica interna de una norma general llamada a ser aplicada en condiciones sustanciales de igualdad.

A partir de estas consideraciones, hilvanar un discurso en contra del art. 139.4 de la LJCA es relativamente sencillo. Queda servida en bandeja, sin duda, la colisión con la previsibilidad, que ha de ser cualidad señera de las costas procesales y, también, con el principio de igualdad en la aplicación de la ley. De hecho, la crítica suele centrarse no tanto en la ausencia de un catálogo claro de supuestos en los que activar este poder, sino sobre todo en el contraste de las cuantías en que se traduce la limitación.

Y no solo eso. A las debilidades achacables al empleo discrecional de la cuantía de la limitación se unen dos derivaciones adicionales todavía más alarmantes: por un lado, la aparición de condenas «simbólicas» que llevan la limi-

las costas procesales en el orden contencioso-administrativo. La reforma de la Ley Orgánica del Poder Judicial», Diario La Ley, 8685, págs. 1282-1289 (pág. 1286). En la misma línea crítica, véase B. Triana Reyes (2016), «El extravagante mundo de las costas procesales en la jurisdicción contencioso-administrativa», Diario La Ley, 8723, págs. 1782-1784.

55 Repárese en la respuesta que la Audiencia Nacional daba recientemente ante la petición de activación del art. 139.4 de la LJCA: «Por otro lado, y en cuanto a la pretensión subsidiaria, el artículo 139.3 LJCA dispone que "La imposición de las costas podrá ser a la totalidad, a una parte de éstas o hasta una cifra máxima”. Ello constituye una facultad del juzgador, y si bien es cierto que el Tribunal Supremo viene limitando la condena en costas a una cantidad máxima en los recursos de casación de que conoce, el criterio de esta Sala es no efectuar esta limitación en la sentencia, con carácter general, sin perjuicio de lo que pueda acordarse en fase de tasación de costas si los honorarios que minute el Letrado de la parte contraria se consideran excesivos» (SAN de 24 de junio de 2015, recurso 215/2014). 
tación al extremo, fijando importes que rayan ciertamente en lo puramente testimonial (epígrafe 3); por otro, la «limitación selectiva» de ciertas partidas, señaladamente de los honorarios del abogado, manera de hacer que ha desencadenado una auténtica crisis en el uso de la facultad que nos ocupa, alterando la normalidad de un devenir hasta ese momento tranquilo (epígrafe 4).

\section{EL FENÓMENO DE LAS CONDENAS SIMBÓLICAS O LA ADVERTENCIA DE UN SERIO PROBLEMA DE ADAPTACIÓN DEL CRITERIO DEL VENCIMIENTO OBJETIVO A CIERTOS CONTENCIOSOS}

Los riesgos de imprevisión y desigualdad no son las únicas disfunciones que se ciernen sobre la cifra máxima. La ausencia absoluta de parámetros legales a la hora de señalar cuáles han de ser, de activarse, los límites de la modulación permite que a través de esta potestad pueda desmontarse la condena en costas en un caso dado. Un tal efecto puede alcanzarse sin más que señalar una suma deliberadamente baja.

El hecho es que esta posibilidad ha sido ya puesta en práctica. Hay así registros de sentencias en las que se establecen como techo cifras bajísimas, casi simbólicas, que no parecen propias del entorno convencional de las costas procesales. Qué decir si no de los pronunciamientos en los que la condena se limita a cantidades que van de los veinte a los cien euros ${ }^{56}$. ¿Está fuera de orden una limitación de esta índole?

En mi opinión, lo está. Es cierto que, gramaticalmente, la escala de limitación del art. 139.4 de la LJCA admite estas condenas simbólicas toda vez que no establece un mínimo a guardar. Sin embargo, esta lectura en clave estrictamente gramatical no me convence. Al moverse en estas cifras, tengo para mí que el poder de limitación sale de sus márgenes naturales y que se desvanece la ratio legis del precepto. Su misión es la moderación de la imposición de costas, no su virtual anulación. Y ese es precisamente el efecto real conseguido. Desprovisto de los ropajes hermenéuticos que acaso le presten parapeto técnico, el resultado real es que se protege al perdedor dando un vuelco a las consecuencias que de tal derrota habría que extraer según el criterio del vencimiento ${ }^{57}$.

56 Sirvan como botón de muestra las siguientes sentencias: SJCA núm. 2 de Barcelona de 6 de octubre de 2014 (recurso 396/2012); SJCA núm. 4 de Barcelona de 21 de enero de 2016 (recurso 172/2015); SJCA núm. 1 de Toledo de 24 de junio de 2016 (recurso 375/2015) y STS de 26 de julio de 2016 (recurso 384/2015) —en cuanto a las costas de la instancia-.

57 Imponer las costas al vencido por imperativo legal y a renglón seguido limitarla como máximo a unos pocos euros raya en el contrasentido. Se diría que la condena en costas deja de ser reconocible como tal. Y, siendo esto así, es dado preguntarse hasta qué punto no se 
He ahí, en la dinámica del vencimiento, a mi juicio, la almendra de las condenas simbólicas. Lejos de constituir una reacción gratuita del juez administrativo representan un anuncio del desencaje del vencimiento objetivo en ciertos lances. Naturalmente, la variedad de registros y la falta de explicaciones dificultan la elucidación de los propósitos exactos que se persiguen con una devaluación así de sustancial ${ }^{58}$. Con todo, las más de las veces, la naturaleza del caso retrata la voluntad del juez administrativo de utilizar esta facultad de limitación en el marco de los pleitos de mínimos o en sectores sensibles como la extranjería a fin de no añadir una arroba más en la derrota del particular que ya ha perdido en su contienda principal con la Administración. Se descubre tirando del hilo una manera de conseguir una condena en costas debilitada, affievolita, que hace frente a la severidad ínsita en el vencimiento ${ }^{59}$.

\section{LA LIMITACIÓN SELECTIVA DE LAS PARTIDAS Y EL GRAVE AGRAVIO COMPARATIVO SURGIDO ENTRE ABOGADOS Y PROCURADORES A RAIIZ DE ESTE MODUS OPERANDI}

Como ya se señaló, el art. 139.4 de la LJCA admite dos variantes: la limitación a una parte de las costas procesales — raramente empleada—o la

está produciendo una denegación de justicia a la parte vencedora teniendo en cuenta la caracterización tan rigurosa que de la regla victus victori viene defendiendo el TC en el sentido de considerar que, allí donde el legislador ha optado por este sistema, su imposición deviene en consecuencia obligatoria que ha acatarse por mor del derecho a la tutela judicial efectiva. Para abundar en esto último puede acudirse a Cierco Seira (2016: 124-125).

58 Incluso cabría elucubrar desde un enfoque totalmente distinto, contemplando la fijación de una cantidad tan baja como una manera de favorecer la efectividad de la condena en costas, en vistas de la probable insolvencia del condenado.

59 El de las condenas simbólicas es, por otra parte, una de las manifestaciones de la reacción del juez administrativo ante la falta de ajustes de la regla victus victori. Pero no es la única. Cabe advertir en la misma línea la utilización del art. 139.4 de la LJCA a fin de mitigar el gravísimo asunto del silencio administrativo. Porque allí donde se lleva a juicio una callada, aunque el particular sea derrotado en su contienda, es llano que en el origen del proceso está la desaplicación de una Administración que ha incumplido su obligación de dar respuesta expresa en plazo. No es de extrañar por ello que, a fin de compensar de algún modo la injusticia que supone premiar con la condena en costas a quien ha promovido la existencia del litigio con una actitud censurable, se vuelva la vista hacia las posibilidades de mitigación que ofrece nuestra regulación, ya en forma de serias dudas de hecho o de derecho (SJCA núm. 3 de Toledo de 13 de julio de 2016, recurso 403/2015), ya al amparo de la facultad limitadora (SJCA núm. 1 de Santander de 3 de febrero de 2016, recurso 316/2015). 
fijación de una cifra máxima — que es la más común—. Ocurre, sin embargo, que en la fragua de la jurisprudencia se ha dado forma a un tertium genus que pasa por imponer un límite a ciertas partidas de las costas procesales.

En efecto, tempranamente se alumbró esta modalidad atemperadora de fijar una cifra máxima pero referida de manera específica a una partida o partidas en concreto. De ella han venido haciendo uso corriente nuestros tribunales, con el Tribunal Supremo a la cabeza. La limitación solía afectar a los gastos de los profesionales intervinientes en la causa. Generalmente, a los honorarios del abogado. En ocasiones, también se han visto afectados los honorarios del procurador. Y, de forma más rara, los honorarios del perito ${ }^{60}$. Insisto en que esta modalidad híbrida devino al poco en la más utilizada. Tan frecuente se hizo en la práctica esta idea de una limitación selectiva de una partida en concreto que allí donde no se tenía a bien proceder de este modo se tendía a indicar de forma expresa que la limitación era "por todos los conceptos», como si se tratase de algo no sobreentendido.

Este alumbramiento, lejos de mejorar la comprensión de esta facultad, ha venido a añadirle algo más de claroscuro. En rigor, esta variante no desborda las posibilidades que ofrece la norma. Combina, por así decir, los dos registros y, en cualquier caso, es de aplicar aquí el conocido argumento a maiore que nos enseña que quien puede lo más puede lo menos. Por otra parte, que se proyecte fundamentalmente sobre los honorarios del abogado parece lógico. Se trata de la partida con más peso en la factura de las costas procesales y, por tanto, es la que está más en grado de descompensar el balance del precio del pleito. A ello hay que añadir que, a diferencia de otros profesionales, señaladamente de los procuradores, los honorarios del abogado no están sujetos a tarifa o arancel — por esta razón pueden ser excesivos en su tasación; los del procurador, por el contrario, no; si acaso indebidos- ${ }^{61}$. Resulta, en fin, probable que en la mens legislatoris este fuese el destino natural del poder de limitación y que sea la del letrado la partida idónea a estos efectos.

Planteamiento insisto que, prima facie, puede antojarse coherente. Sin embargo, en su interior alberga un grave e irresoluble problema que sale a plaza allí donde se da una combinación, por lo demás, perfectamente realizable: que se limiten únicamente los honorarios del abogado y que, como consecuencia de la cuantía del pleito, resulte que el montante a percibir por el procurador sea superior.

\footnotetext{
60 Sirva para ilustrarlo, por ser este el registro más raro, la STSJ de Madrid de 4 de mayo de 2015 (recurso 615/2013).

61 Véase el art. 245 (Impugnación de la tasación de costas) de la LEC.
} 
Pongamos cifras a lo anterior. Imaginémonos un pleito cuya cuantía sea altísima, de cincuenta y siete millones de euros, en el que el juez administrativo opte por limitar la imposición de costas en concepto de abogado a veinticinco mil euros; y en el que, sin limitación que le afecte, el procurador reclame un arancel cuatro veces superior. ¿Tiene sentido esta situación? Parece claro que no por algo elemental: en el desenlace del pleito el trabajo del abogado posee una incidencia mayor, lo cual habría de corresponderse, en buena lógica, con el coste de sus servicios. Pues bien, los datos expuestos, lejos de la simple hipótesis, proceden de un caso real: el fallado por la STS de 20 de abril de 2010 (recurso 3337/2007) y luego, en incidentes de costas y nulidad de actuaciones, por los respectivos AATS de 19 de julio de 2011 (JUR 2012/55047) y 15 de noviembre de 2011 (JUR 2011/408404) ${ }^{62}$.

En el origen del caso hallamos una importante sanción en materia de defensa de la competencia que vino anulada judicialmente con la consecuente condena en costas a la Administración. Sin entrar ahora en otros pormenores, señalaré que, luego de limitar la remuneración posible del abogado, el TS decidió hacer lo propio con el procurador a fin de dispensar a ambos profesionales un trato equivalente, evitando un agravio en la valuación de su intervención. El derecho del procurador quedó de esta suerte reducido a algo más de doce mil euros, la décima parte, aproximadamente, de lo que en teoría resultaba de recibo según el arancel.

Ocurría, no obstante, que una tal corrección tropezaba con dos inconvenientes de entidad. Inconvenientes de los que el TS era, por lo demás, consciente. No en vano, el ATS de 19 de julio de 2011, que contiene el pronunciamiento principal al respecto, destaca por su profusa motivación y por el armazón argumental que se articula en orden a justificar la activación del poder de limitación del art. 139.4 de la LJCA. Un poder que, por lo común, como ya nos consta, raramente aparece flanqueado por largas explicaciones.

El primer obstáculo tenía que ver con el momento de activación de la facultad de moderación. Y es que la limitación de los derechos arancelarios hubo de practicarse después de haberse dictado sentencia, en fase de tasación de costas procesales. La tardía aplicación exigía justificar por qué no se tocó la tecla más atrás pero, sobre todo, exigía descartar una eventual preclusión del poder una vez dictada la sentencia. A tal efecto, el TS se apoyó en el generoso quantum de discreción que concede el art. 139.4 de la LJCA. Después de

62 Un detenido análisis del capítulo que va a narrarse puede encontrarse en José Ramón Rodríguez Carbajo, "Revolución en el régimen de las minutas de los Procuradores en los procesos contencioso-administrativos», Actualidad Administrativa, núm. 10, 2013, págs. 6 y ss. 
todo, siguiendo el razonamiento del alto tribunal, nada impide, con el texto en la mano, que la limitación tenga lugar a posteriori ${ }^{63}$.

El segundo obstáculo revestía más envergadura. Porque sucede que los derechos arancelarios de los procuradores, a diferencia de los honorarios del abogado, vienen nada menos que baremados normativamente en el Reglamento del arancel de derechos de los procuradores de los tribunales ${ }^{64}$. Su limitación, pues, suponía hacer abstracción de lo previsto en una norma dictada con el propósito específico de establecer un modelo tasado de arancel en la retribución del procurador ${ }^{65}$.

Para sortear tal escollo, el TS basó su posición en la invocación del principio de proporcionalidad traído a colación como manifestación de una corriente general de liberalización y moderación de la retribución de los servicios profesionales; tendencia que ya habría llegado al abogado y que sería del todo natural extender al procurador ${ }^{66}$. Así las cosas, el art. 139.4 de la LJCA, gracias a su carácter tan abierto, proporcionaría una vía para vehicular la idea de moderación, «adelantando» en cierto modo un cambio de paradigma en ciernes ${ }^{67}$. Por otra

63 El razonamiento se expresa en los siguientes términos: «Si tal facultad de fijar la cifra máxima de costas a cargo del vencido puede hacerse por la Sala libremente a priori (esto es, antes de la tasación pormenorizada de las costas) y ello pudiera implicar la no sujeción estricta a las reglas arancelarias, ninguna razón de fondo existe para que, en casos de manifiesta desproporción, el tribunal no atempere también a posteriori, hasta un determinado máximo, el importe de los derechos económicos del Procurador que pueden ser cargados al condenado en costas».

Esta activación a posteriori tendría, además, la ventaja de que se produciría en un momento en el que el órgano jurisdiccional dispone de más elementos de juicio para valorar la conveniencia de la limitación. A la vista de las liquidaciones practicadas, resultaría, en efecto, más sencillo apreciar las posibles disfunciones del impacto económico del pleito sobre la parte vencida.

64 Aprobado mediante el RD 1373/2003, de 7 de noviembre.

65 No en vano, precisamente en razón de la naturaleza arancelaria de su retribución, el TS había venido circunscribiendo habitualmente el radio de acción del art. 139.4 de la LJCA a la remuneración, no tasada, del abogado.

66 La existencia de esta corriente es fácil de reconocer a juicio del TS. Digamos que hay en el ambiente no pocas señales evidentes, destacando entre ellas el Real Decreto Ley $5 / 2010$, de 31 de marzo. Su presencia es crucial en el discurso del TS porque en el mentado Real Decreto Ley se contiene un alegato a favor de la necesidad de combatir la aparición de liquidaciones manifiestamente desproporcionadas por parte de los procuradores. Alegato que se traduce en la fijación de un tope máximo (disposición adicional única) y de ciertas precisiones para los procesos concursales.

67 A la espera, pues, de la reforma normativa correspondiente en materia de retribución del procurador, el art. 139.4 de la LJCA proporcionaría un valioso y oportuno baipás. 
parte, gozando de cobertura legal, el poder de limitación bien podía imponerse por jerarquía al arancel reglamentario y superar sus rigideces.

Finalmente, el discurso tejido se cerraba con el intento de reconducir la genuina finalidad del art. 139.4 de la LJCA haciendo hincapié en que la limitación no pretende sino proteger a la parte vencida, sobre la que pesan las costas procesales, fuera de todas las connotaciones que, desde la óptica profesional, adquieren estas últimas como extra de ganancia. No ha de ser el profesional, abogado o procurador, el destinatario principal de la limitación, por más que acabe viéndose afectado. Dicho en otras palabras: que se limiten las costas no ha de interferir en la retribución a cobrar por aquel y que tendrá su origen en lo pactado con el cliente, defendido o representado ${ }^{68}$. Es, por el contrario, la parte vencida la protagonista; a ella va destinada la moderación y a ella, en definitiva, va a beneficiar que se dicte una condena en costas mitigada - y asoma así la protección del derecho de acceso a la justicia administrativa que es, a mi modo de ver, el auténtico norte que habría de seguirse en la aplicación del art. 139.4 de la LJCA.

A pesar del aparato argumental exhibido, este posicionamiento del TS iba a tener un breve recorrido. Dos votos particulares dejaban entrever ya la fractura, especialmente en lo que suponía de inaplicación de un régimen de arancel y de abierta reconsideración, al margen de una norma ex professo, de lo que ha de ser la retribución justa y equitativa del procurador.

En efecto, iba a ser el propio TS quien volviese sobre sus pasos, sometiendo para ello el tema a la consideración del pleno. Así, en dos autos de fecha 5 de marzo de 2013 (recursos 2495/2009 y 3678/2010) se retomó la problemática con la voluntad de ordenar y sentar un criterio común sobre el particular ${ }^{69}$. Para ello, el alto tribunal decidió trazar una especie de via di mezzo sobre la base de una limitación de la discreción del poder de moderación que habría de actuar sobre el quando, dejando a salvo, en cambio, el quid. De suerte que el art. 139.4 de la LJCA podría ser invocado solo en el momento de imponer las costas, en consonancia con su enunciado literal — «La imposición de las costas podrá ser...»—. Limitado el cuando, se dejaba vía libre, sin embargo, para actuar sobre todas y cada una de las partidas, incluida la del procurador. Y ello

68 «No se olvide — afirma el TS — que una cosa es la cantidad que debe pagar la parte que pierde el juicio en concepto de costas y otra, bien distinta, la cantidad que cobran de su cliente los abogados o procuradores, que estará en función de lo que hayan convenido». Se nos recuerda, por tanto, que hay en las costas una relación obligacional en cuyo reverso aparece la deuda que recae sobre la parte condenada y en cuyo anverso encontramos el crédito a favor de la parte vencedora, no del profesional encargado de su defensa o representación.

69 Posición luego reafirmada en el ATS de 11 de julio de 2013 (recurso 2742/2010) y que es la que llega a nuestros días. 
no ya en tributo al discurso contemporáneo de contención en el precio de los servicios profesionales. En rigor, no es preciso recabar apoyo externo para moderar los derechos económicos del procurador. El ancho margen de discreción del art. 139.4 de la LJCA brindaría, sin necesidad de forzar sus palabras y las reglas hermenéuticas, la posibilidad de hacerlo ${ }^{70}$.

Pero es que, además, el ATS de 19 de julio de 2011, ojo del huracán, motivó que el procurador afectado impetrase, por la vía del recurso de amparo, la protección del Tribunal Constitucional ${ }^{71}$. Protección que llegó toda vez que en la STC 108/2013, de 6 de mayo, se vino a reconocer la existencia de una lesión del derecho a la tutela judicial efectiva de dicho procurador, en la concreta vertiente que atañe al derecho a obtener una resolución motivada y fundada en derecho ${ }^{72}$. En efecto, el TC estimó en ella que el auto controvertido acusaba un déficit de motivación en la medida en que hacía pivotar su ratio decidendi sobre un principio de proporcionalidad en la retribución del procurador que no se colegía de la normativa y se traducía en la inaplicación de un reglamento sin una explicación cabal que así lo justificase ${ }^{73}$. Además, no era el incidente de tasación de costas el momento oportuno para hacer uso del poder de limitación; la moderación a posteriori, la «repesca» de este poder, en el entender del TC, no era admisible ${ }^{74}$.

70 La lectura de la serie de autos y votos particulares evidencia, amén de la existencia de un debate vivo en el seno del TS, un esfuerzo mayúsculo por tratar de acertar con la inteligencia del sistema arancelario de los procuradores a la luz del signo de los tiempos actuales.

71 La entidad del conflicto se hace evidente al comprobar que el recurso de amparo fue promovido no solo por el procurador afectado sino que éste contó con el respaldo del Consejo de Procuradores de Madrid y el Consejo General de Procuradores de España.

72 Sostenía el procurador que también se había conculcado su derecho a la igualdad en la aplicación de la ley argumentando que en casos semejantes el TS no había procedido a limitar esta partida de las costas. El TC, sin embargo, rechazó esta alegación por considerar que las sentencias aportadas como elemento de comparación no resultaban válidas al proceder de secciones del TS distintas a la autora del auto en liza.

73 A pesar de que la STC 108/2003, de 6 de mayo, respalda el cambio de rumbo fijado por el TS, no deja de ser insólito el amparo concedido, especialmente porque avala la presencia de un vínculo directísimo entre las costas y el procurador, al margen, pues, de la parte vencedora. Extremo que, ciertamente, parece apartarse de la caracterización tradicional de las costas procesales a la que ya se hizo mención — véase así la posición mantenida por el fiscal en el recurso de amparo, así como las críticas efectuadas en el ATS de 11 de julio de 2013 (recurso 2742/2010).

74 Tajante es al respecto el máximo intérprete de la CE: «de su redacción [hace referencia al art. 139.4 de la LJCA] resulta pues que su ejercicio está circunscrito al momento de la imposición de las costas, sin que pueda realizarse en un momento posterior» (FJ 5). 
¿Qué conclusiones se extraen al cabo de todo este episodio? Si nos ceñimos a lo estrictamente superficial, ha quedado bien establecida una limitación en el uso del poder de limitación. En adelante, el juez administrativo ha de tener claro que el art. 139.4 de la LJCA solamente puede ser aplicado al tiempo de imponer las costas procesales en el pronunciamiento que sea, no en sus derivaciones posteriores, es decir, en la sentencia o en el auto que resuelvan la imposición de costas mas no en el incidente de tasación.

En el fondo aguarda, no obstante, otra conclusión. La moraleja es que el invento de la limitación selectiva es claramente desaconsejable. La limitación selectiva no hace bien a este poder de moderación y le ha supuesto un desgaste innecesario, situándolo en una tesitura con predominio del componente colegial - véase si no el eco que tuvo el caso y el papel tan activo que desempeñó en él el Consejo General de Procuradores de Espańa-. Un dispendio de energías y esfuerzos que, en lugar de contribuir a afirmar la roca sobre la que ha de asentarse el art. 139.4 de la LJCA, ha desviado el centro de atención hacia cuestiones que debieran ser secundarias en el devenir de este poder. Sea como fuere, el TS ha tomado buena nota de todo ello. Sin perjuicio de todo un reguero de casos en los que el cambio de criterio ha pillado a pie cambiado, con la consiguiente confirmación de la anomalía descrita - mayor importe de los derechos del procurador no limitados en contraste con los honorarios limitados del abogado ${ }^{75}$ _, se aprecia con tersura un abandono de la limitación selectiva por parte del Alto Tribunal. Predomina en su lugar ahora la limitación "por todos los conceptos» y es de imaginar que esta va a ser la modalidad que acabará imponiéndose a partir de este momento en todo el panorama judicial ${ }^{76}$.

A mi entender, supuestos los términos del razonamiento, la conclusión alcanzada no solamente es predicable en relación con los derechos del procurador, sino, en realidad, con cualquier partida de las costas procesales. Estas han de limitarse al tiempo de imponer las costas sin que sea admisible su puesta en marcha durante la fase de tasación. No lo consideró de este modo, sin embargo, el TS en su auto de 12 de noviembre de 2013 (JUR 2014/3148), donde justificó la posible moderación a posteriori respecto de la minuta del abogado.

75 Gráfico al respecto es el ATS de 21 de marzo de 2014 (recurso 673/2012): los honorarios del letrado habían sido limitados a 4000 euros; el procurador giró tasación por valor de más de 11000 euros. Son casos como estos, situados en el ínterin, los más beneficiados por las consecuencias de este río revuelto.

76 Al final, por tanto, los derechos arancelarios del procurador se limitan, solo que dicha limitación tiene lugar al tiempo de imponerse las costas y no después. No son necesarios rodeos argumentales al respecto; el art. 139.4 de la LJCA se basta por sí solo; es poder suficiente para doblegar el régimen arancelario; eso sí, es poder a ejercer en un 


\section{POR UNA REFORMA LEGAL SUSTANCIAL DE NUESTRO SISTEMA DE COSTAS PROCESALES Y UNA RECONSIDERACIÓN EN CLAVE JUDICIAL DE LA FORMA DE MOTIVAR LA UTILIZACIÓN DE SUS ACTUALES RESORTES}

A. Llegados a este punto es llano que el poder de limitar las costas procesales aparece rodeado de no pocos claroscuros. Siendo esto así, ¿conviene que el régimen de las costas procesales en la justicia administrativa venga coronado por una cláusula de este tenor o habría que proceder a su reforma o aun derogación?

En el debe sobresale, sin duda, la incertidumbre que envuelve su manejo. Hoy, el torrente de críticas que recibe en este sentido resulta difícil de ignorar. Y no solo por la claridad de los argumentos expuestos, sino aun por lo tangible que resulta, con sentencia en mano, apreciar las disfunciones denunciadas. Los alegatos en contra proceden, por lo demás, de quienes se mueven a diario por los escenarios judiciales. Y no se piense solo en los abogados y procuradores de parte. Las voces que alertan de la inseguridad que se cierne sobre el art. 139.4 de la LJCA provienen también de las filas de la judicatura ${ }^{77}$. La STC $108 / 2013$, de 6 de mayo, hasta el momento el más firme aldabonazo, muestra solamente la punta de un iceberg que hace tambalear el principio de igualdad en la aplicación de las normas sobre costas procesales. No es sostenible que la interpretación de la derrota en términos de costas procesales presente variaciones tan sustanciales en función del órgano jurisdiccional de turno.

Con todo, he de romper una lanza a favor de esta previsión. Porque, en mi sentir, en el balance son más las virtudes que acumula. Abogo, pues, por su continuidad, no sin reconocer, por supuesto, sus debilidades y, sobre todo, significando la conveniencia de una remodelación cabal con vistas a proveerle de un encuadramiento más seguro y, por ende, previsible.

El art. 139.4 de la LJCA conviene a la justicia administrativa de nuestros días. Y ello en razón de que su misión constituye un valioso baluarte de la

solo acto, por lo que es preciso que el juez administrativo se forme de antemano una idea precisa del alcance que quiere dar a la limitación de las costas.

77 J. R. Chaves García (2015), Versiones y perversiones de los criterios de imposición de costas en lo contencioso-administrativo, Discurso de ingreso en la Real Academia Asturiana de Jurisprudencia, Oviedo (pág. 46), después de una minuciosa y aguda exposición del status quaestionis de las costas procesales en la justicia administrativa, concluía que «el escenario jurídico en la aplicación por la jurisdicción contencioso-administrativo del manido art. 139 LJCA está plagado de incertidumbres en múltiples frentes. Además la fragmentación o balcanización de criterio, unida a la dificultad de consolidar criterios jurisprudenciales vinculantes, aboca a situaciones de clamorosa injusticia. La seguridad jurídica padece con normas de eficacia impredecible». 
idiosincrasia de esta rama jurisdiccional. La posibilidad real de que el particular pueda someter a escrutinio judicial la actividad de la Administración exige estar en guardia ante los obstáculos que dificultan el acceso a los tribunales, especialmente en lo que hace a la primera instancia. $Y$ es desde esa concreta perspectiva, la de velar por la efectividad del acceso a la justicia administrativa, por mor de la tutela de los derechos e intereses de los particulares, pero también de lo que supone el control judicial de la Administración en la inteligencia del imperio de la ley, desde la que el art. 139.4 de la LJCA merece ser preservado a modo de cláusula de cierre. Cláusula de cierre tendente a moderar el impacto económico de lo que para las partes va a suponer su paso por el proceso judicial. Dicho en otras palabras, cláusula para ajustar el "precio» de litigar a la luz de las circunstancias del caso y de lo singular del contexto contencioso-administrativo en el que resulta a veces una proeza, un auténtico tour de force, llevar a la Administración ante los estrados ${ }^{78}$.

Solo haciendo alto en su misión en el sistema de derechos fundamentales cabe descubrir la roca firme necesaria para defender la continuidad del poder de limitación de las costas procesales apelando al prudente arbitrio del juez administrativo. Apoderar al órgano jurisdiccional para que limite el peso de las costas procesales encaja así a la perfección con una corriente que ve con buenos ojos la posibilidad de que el juez pueda ajustar casuísticamente el impacto de los obstáculos económicos que marcan el acceso a la justicia. Corriente que está muy presente en la jurisprudencia del Tribunal Europeo de Derechos Humanos en materia de tasas judiciales ${ }^{79}$. Digamos en compendio que se considera que, en razón de su proximidad y del conocimiento de la causa, es el juez el mejor situado para llevar a cabo un balance entre lo que representa el "precio» del pleito y sus circunstancias. Una cláusula de limita-

$78 \mathrm{Al}$ asomarnos al derecho comparado vemos que existen previsiones de este orden que buscan dotar al juez administrativo de un poder de apreciación para modular la distribución de los gastos del proceso. En Francia, sin ir más lejos, se contempla el poder de desactivar o limitar la condena al perdedor a propósito de los denominados frais irrépétibles — donde se incluyen los honorarios del abogado—, teniendo en cuenta la situación económica de la parte condenada o incluso por mor de la equidad. El art. L761-1 del Code de justice administrative dice así: «Dans toutes les instances, le juge condamne la partie tenue aux dépens ou, à défaut, la partie perdante, à payer à l'autre partie la somme qu'il détermine, au titre des frais exposés et non compris dans les dépens. Le juge tient compte de l'équité ou de la situation économique de la partie condamnée. Il peut, même d'office, pour des raisons tirées des mêmes considérations, dire qu'il n'y a pas lieu à cette condamnation".

79 A ella me he referido en C. Cierco Seira (2014), Tasas judiciales y justicia administrativa, Madrid: Marcial Pons (págs. 95-104). 
ción ad cassum constituye, bajo esta óptica, una formidable reserva para que, en última instancia, puedan tomarse en consideración una serie de variables que acaso hayan escapado a los filtros estatuidos — comenzando por la justeza de la posición mantenida, pero también la naturaleza del litigio, el comportamiento de las partes, la situación de los actores, entre otras muchas- y que pueden contribuir a esa reflexión sobre el impacto del coste económico del proceso judicial y la necesidad de que no desborde las exigencias del derecho de acceso a los tribunales en condiciones razonables - id est: asequibles ${ }^{80}$.

Esto sentado, la calidad de una cláusula de cierre, por más que sirva al propósito de preservar la efectividad del derecho de acceso a la justicia administrativa, exige que la flexibilidad, necesaria, sí, se conjugue adecuadamente con la previsibilidad ${ }^{81}$. Diversas son a partir de aquí las ecuaciones posibles. Pero lo que no es admisible es la renuncia al esfuerzo de precisión, pensando que a fuer de insistir en la singularidad no queda más remedio que acabar en brazos de la incertidumbre como parte del paisaje y del ingenio y audacia de quien tiene la última palabra ${ }^{82}$.

80 Supone lo anterior dotar a este poder de una identidad clara, de una roca firme sobre la que asentar una imagen reconocible; identidad de la que hoy carece, sumergida como está bajo una auténtica mezcolanza de propósitos. Otra cosa es que esa identidad, vinculada al acceso a la justicia administrativa, cueste todavía de interiorizar. Hace falta que en el discurso sobre el ideal de este orden jurisdiccional cale todavía más la sensibilidad por el precio de pleitear contra la Administración y sobre lo determinante que pueden llegar a ser los obstáculos económicos. En este sentido, el trance reciente de las tasas judiciales, con su particular periplo, debería servir al menos para tomar conciencia del importante peso del factor económico en la justicia. Si al final se da por buena simplemente la vuelta a la casilla de salida —a base de ir desmontando el apresurado andamiaje de la Ley de tasas judiciales de 2012; después de recular en parte el legislador (Real Decreto-Ley 3/2013, de 22 de febrero y Ley 25/2015, de 28 de julio), ha llegado ahora el turno del TC: STC 140/2016, de 21 de julio- creo que habremos perdido una formidable oportunidad para aprender de la experiencia y reflexionar con hondura sobre la financiación de la justicia y la lucha contra la litigiosidad a fuerza de encarecer su uso. Véase E. Montoya Martín (2014), «Incidencia de la crisis económica sobre la justicia», en Por el Derecho y la libertad, Libro Homenaje al Profesor Juan Alfonso Santamaría Pastor, v. I, Madrid: Iustel, págs. 473-499.

81 Hace aquí al caso recordar el compromiso que tiene el legislador en cuanto a la necesidad de proveer de la mayor densidad de regulación posible en torno al arbitrio judicial a fin de favorecer el recto uso de la discreción. Véase T.-R. Fernández (2005), Del arbitrio y de la arbitrariedad judicial, Madrid: Iustel (págs. 87-91).

82 La primera y fundamental consecuencia de cohonestar la flexibilidad del poder de limitar las costas procesales con su carácter previsible es la necesidad de estatuir sin falta parámetros legales que reduzcan la incertidumbre actual y orienten hacia dónde 
B. La observación de la forma en que viene aplicándose el art. 139.4 de la LJCA revela que en ciertos lances se hace un uso forzado del mismo aprovechando la notable discreción de su tenor literal y la ausencia de una guía clara sobre su funcionalidad.

ha de dirigirse el uso de este poder. Cuáles hayan de ser esos parámetros es cuestión, por supuesto, capital. Sin embargo, me temo que en este caso el trabajo desarrollado hasta ahora por nuestros tribunales no está en grado de dispensar al legislador la base para llevar a cabo simplemente una cristalización de su hallazgo en la ley. Sin olvidar que la lista de motivos es de hecho amplísima, considero que, ciñéndonos ahora a los más invocados, solo el relativo a la «entidad del pleito» debería ser rescatado. Por el contrario, orillaría de este elenco a la «actividad desplegada» pues, después de todo lo expuesto, salta a la vista la confusión que genera en todos los órdenes.

Entidad del pleito, eso sí, tamizada y orientada al examen de la singularidad del caso, lo que permitiría enlazar ora con la problemática que gira en torno a los pleitos menores, ora con la naturaleza de ciertas pretensiones deducidas y la existencia de ámbitos de la justicia administrativa especialmente sensibles a los obstáculos económicos.

Por otra parte, aunque en la obra pretoriana de nuestro juez administrativo solo aparezca a cuentagotas, entiendo que convendría acuñar legalmente un segundo criterio, cuya justificación no resultaría en absoluto difícil de desarrollar y que vendría a guardar, además, las posibles limitaciones que nuestro sistema de justicia gratuita reviste. Estoy pensando en la capacidad económica de la parte vencida atendido el contexto del pleito y los datos aportados a tal fin; se trataría de atender, pues, no solo a las circunstancias del hecho del proceso en sí, sino también puestas en relación con la realidad personal de la parte condenada. Destaca en este sentido el meritorio ejercicio de interpretación que alberga la STSJ de Cantabria de 17 de junio de 2016 (recurso 309/2014) acerca de la virtualidad del precepto que nos ocupa, sus limitaciones y sus virtudes. Después de un concienzudo razonamiento, cuya consulta es de aconsejar, el tribunal llega a la importante conclusión de que, con vistas a ofrecer en lo sucesivo un marco seguro al art. 139.4 de la LJCA, el criterio que mejor se ajusta a su funcionalidad y posición en el sistema de costas procesales es el relativo a la capacidad económica de la parte vencida. Aunque el fragmento es largo, merece la pena transcribirlo aquí: "A nuestro parecer, el criterio que mejor responde a las líneas orientadoras que he expuesto, es el económico, centrado en las posibilidades económicas de la parte "vencida". Si pensamos en un valor jurídico que puede ponerse frente al derecho de la parte "ganadora" a la compensación por el gasto que le ha ocasionado obtener ante los tribunales la tutela de su posición, es decir el ejercicio del derecho proclamado en el art. 24.1 de la Constitución; inmediatamente surge el mismo derecho de la parte "vencida”, en su dimensión de acceso a la jurisdicción y en su relación con los medios suficientes para ejercer tal derecho. Y así, puede sostenerse que, si la insuficiencia de medios (en los términos que establece la doctrina del TC: imposibilidad de sostener el coste de un pleito sin prescindir de las condiciones de una vida digna) conduce a 
Es ese, íntimamente ligado a la incertidumbre, otro de los grandes peligros que acechan a este poder de limitación: que se pierda el que ha de ser su norte y se oriente al cabo al servicio de fines que en principio le son ajenos, como la facilitación de la labor de tasación de las costas procesales o la neutralización virtual e indirecta de la regla del vencimiento. Cosa que, por otra parte, nos pone sobre la pista de ciertas disfunciones de la justicia administrativa respecto de las cuales el art. 139.4 de la LJCA viene a ser una suerte de luz de alerta. Dos son, en concreto, las disfunciones advertidas.

a. Está, por un lado, el arisco y complejo tema de la valuación o tasación de las costas procesales con todos los recelos e intereses que giran a su alrededor. La fijación de un techo por la vía rápida del art. 139.4 de la LJCA acaso se antoje, habida cuenta de la contundencia del resultado, una receta propicia. Lejos de ello, constituye, a mi modo de ver, un remiendo incapaz de dar al traje la consistencia que precisa. Si resulta que las costas procesales se prestan a la desmesura; si la cuantificación de ciertas partidas suele tambalearse por la imprecisión; si la justipreciación del proceso presenta vías de agua; si no se tiene claro, en resolución, el "precio» de la justicia administrativa es llano que nos enfrentamos a un problema estructural y, por cierto, no de paja, que en modo alguno puede resolverse a base de invocar una cláusula excepcional. Lo

ver la justicia gratuita como contenido del derecho de accesos a la jurisdicción, cabe atender a situaciones próximas al límite legal del beneficio de justicia gratuita como criterio de aplicación del art. 139.3; lo que, obviamente requiere la alegación y prueba del que pretenda tal aplicación. Es este un criterio que tiene la virtualidad de separar claramente la potestad jurisdiccional de limitar las costas en la sentencia, de la fase de tasación de costas, que no es competencia del tribunal (a salvo los recursos las decisiones de los letrados de la Administración de justicia)».

Además de estos parámetros, bueno sería que se remarcase expressis verbis que se está ante una potestad de orden excepcional, llamada, esto es, a actuar en defecto de los mecanismos de atenuación ya previstos en el modelo de costas procesales. $\mathrm{He}$ ahí de hecho una de las premisas fundamentales para su adecuada interpretación. Ondeando la bandera del vencimiento, la aplicación del art. 139.4 de la LJCA exige más que nunca la espera discreta, aguardando en un segundo plano. Solo después de descartar las vías de mitigación que ofrecen la complejidad del caso, en forma de serias dudas de hecho o de derecho, así como la derrota parcial —ambos expresión de los clásicos cánones de la ricorrenza di giusti motivi y de la soccombenza reciproca, respectivamente-, debería ser dado acudir a la previsión de marras.

Sin olvidar, en fin, la importancia de la motivación. Un mandato legal específico podría ayudar, qué duda cabe, a salir del estado de relajación en que estamos instalados en la actualidad. Con todo, el cambio ha de protagonizarlo el juez administrativo. No se trata de exigir al respecto una explicación fuera de orden, que acaso podría llegar 
único que se consigue al obrar de este modo es poner al descubierto las limitaciones del art. 139.4 de la LJCA y depositar sobre él una responsabilidad que, guste o no, le desborda ${ }^{83}$.

b. Otro tanto ocurre cuando se acude al art. 139.4 de la LJCA para neutralizar de forma velada la rigidez de la regla objetiva del vencimiento en ciertos tipos de pleitos.

Hay signos evidentes de que el desembarco final del criterio del vencimiento en la primera instancia de lo contencioso-administrativo se ha hecho con más ímpetu y brío que meditación. Con la voluntad de combatir una litigiosidad desbocada pero sin parar mientes en la variedad de temas que hoy se residencian en la justicia administrativa y en su naturaleza y aptitud para resentirse frente a los obstáculos de orden económico. Una parte del discurso que fundamenta el ideal de defensa del derecho sin daño patrimonial, de la recuperación a ultranza del gasto de litigar con razón, no encaja del todo cuando se proyecta sobre la materia administrativa y sobre un enfrentamiento entre partes que no conservan una posición recíproca de partida. No me cabe la menor duda de que acertar con el equilibrio hubiera requerido de un modelo atenuado de vencimiento que no fuese, como es hoy, un simple calco del que

a ser, por su complejidad, contraproducente. Es claro que una cláusula de este signo, apegada a la equidad y, por tanto, a la íntima convicción del juzgador y su cercanía al caso, no puede desgranarse cual si se tratase de una fórmula matemática. Pero sí conviene que se brinde una motivación suficiente y que, de este modo, se ayude a trazar un rumbo, con todos los matices que se presume como peaje del casuismo, pero previsible en su dirección general.

Parámetros, carácter extraordinario y exigencia de motivación. Tres extremos, en mi opinión, que deberían abordarse en una reformulación del poder de limitación de las costas procesales en la justicia administrativa. Exigencias sencillas que ayudarían a dar otra luz al tema que nos ocupa.

83 Que los mentados son asuntos que preocupan lo demuestra le lectura de los trabajos realizados en torno a la Propuesta de anteproyecto de Ley de eficiencia de la Jurisdicción Contencioso-Administrativa (Ministerio de Justicia, 2013). Entre las reformas que proponía este texto figuraba una reformulación de la determinación de las costas procesales en concepto de abogado y procurador. A fin de que el recurrente estuviese en grado de calcular mejor el coste de litigar y evitar al mismo tiempo las complicaciones a que lleva el procedimiento de tasación, se apostaba por baremar reglamentariamente los gastos de abogado y procurador a través de una tabulación. Tabulación que habría de basarse en la retribución razonable de un profesional medio y que vendría fijada por el Gobierno mediante Real Decreto, previo informe de la Comisión Nacional de la Competencia. 
viene operando en la justicia civil. Un modelo de costas procesales diseńado ad hoc ${ }^{84}$.

Sin alejarnos tanto, lo cierto es que la recepción del vencimiento ha sido todo un éxito en lo que hace a la contención de la tasa de litigiosidad. La vis disuasoria que es santo y seña de la regla victus victori ha surtido efecto. Eso sí, se está pagando a cambio un precio significativo que se revela en múltiples facetas; en lo que aquí importa, en la desatención a ámbitos de la actuación administrativa que requieren de una facilitación en el acceso a los tribunales a la luz de los derechos e intereses comprometidos. Que el art. 139.4 de la LJCA venga al rescate no es una buena noticia. Sí, en lo que representa de atención vigilante del juez administrativo para con el equilibrio económico del hecho del proceso y la búsqueda de una solución ponderada y justa. Pero su sustancia artesanal no se compadece con el enderezamiento de lo que es una disfunción estructural que llama a actuar sobre los cimientos ${ }^{85}$.

84 Si algo ha dejado claro la historia de las costas procesales en nuestro proceso contencioso-administrativo es que las categorías traídas del proceso judicial común experimentan ciertas transformaciones cuando se exponen a la idiosincrasia de la justicia administrativa. Tenemos a la mano la trayectoria de la temeridad y su tortuosa, confusa e insatisfactoria aplicación. Pues bien, el vencimiento, traído tal cual nuevamente de la cantera del proceso judicial civil, acusa, naturalmente con otras connotaciones, problemas de ajuste de la misma naturaleza. Se da por hecho que se producirá una adaptación espontánea al contexto, pero las cosas no son tan sencillas. El juez administrativo, en definitiva, tiene buenas razones para exigir que la ley procesal le provea de herramientas apropiadas porque el desafío, que lo es en mi opinión, las requiere. Insisto, de todos modos, que la utilización del art. 139.4 de la LJCA in extremis como vía para mitigar la dureza del vencimiento objetivo en según qué ámbitos es solo un indicador de la falta de ajustes en el acoplamiento. Indicador que se suma a otros que cabe encontrar en la densa obra jurisprudencial. Muy llamativa me parece en este sentido la resistencia que algunos tribunales ofrecen frente al fenómeno del silencio administrativo. Condenar en costas al particular que ha perdido un recurso interpuesto contra una denegación presunta puede chirriar si entonamos el canto de la responsabilidad por el hecho del proceso. De ahí que en ocasiones se busque soslayar la aplicación del vencimiento a tiralíneas por las vías de atenuación que ya conocemos o aun de manera más frontal, yendo más al derecho, apelando a la esencia de las costas procesales como institución al servicio del hecho del proceso y de sus causas: «No se aprecian causas o motivos que justifiquen realizar un especial pronunciamiento impositivo sobre las costas procesales causadas en este procedimiento, de conformidad con lo dispuesto en el art. 139 de la LJCA, dado que aun cuando ya rija el criterio del vencimiento objetivo y se haya desestimado la demanda, lo que determinaría que las costas fueran impuestas al recurrente, sin embargo, el silencio en vía administrativa de la Administración demandada, determina que no proceda hacer dicha imposición 
El poder de limitar las costas procesales por parte del juez administrativo debiera ser, en definitiva, el broche de un sistema de costas procesales diseñado a conciencia y a tono con la singularidad de esta rama jurisdiccional. He ahí la piedra angular que ha de servir de base o fundamento para que el precio de litigar contra la Administración sea al fin siempre razonable.

pues no procede condenar en costas a quien solicita la intervención de los tribunales de justicia por no conocer los argumentos de la Administración frente a la pretensión ejercitada en vía administrativa, al incumplir esta su obligación de resolver de forma expresa. El silencio en vía administrativa ante la solicitud de la actora determina que no pueda realizarse imposición de costas procesales a la parte recurrente» (STSJ de Castilla y León de 4 de septiembre de 2015, recurso 16/2014).

Es discutible que un tal planteamiento tenga cabida entre los márgenes que ofrece el sistema de vencimiento vigente en la LJCA, más aún a la luz de la doctrina constitucional que enseña que siendo la imposición de carácter imperativo — que lo es en primera instancia con arreglo al art. 139.1 de la LJCA — no hay margen de discreción y la condena en costas se convierte en una "consecuencia inescindible» de la estimación de la pretensión (el arrêt fundamental lo constituye la STC 25/2006, de 30 de enero). Pero, sea como fuere, muestra a las claras la presencia de una disfunción inquietante en lo que atañe al tratamiento procesal del silencio administrativo y las costas procesales. 
